Portland State University

PDXScholar

\title{
Creating a Learning Continuum: A Critical Look at the Intersection of Prior Knowledge, Outdoor Education, and Next Generation Science Standards Disciplinary Core Ideas and Practices
}

Trisha Leigh Schlobohm

Portland State University

Follow this and additional works at: https://pdxscholar.library.pdx.edu/open_access_etds

Part of the Educational Methods Commons, and the Science and Mathematics Education Commons Let us know how access to this document benefits you.

\section{Recommended Citation}

Schlobohm, Trisha Leigh, "Creating a Learning Continuum: A Critical Look at the Intersection of Prior Knowledge, Outdoor Education, and Next Generation Science Standards Disciplinary Core Ideas and Practices" (2016). Dissertations and Theses. Paper 2749.

https://doi.org/10.15760/etd.2750

This Thesis is brought to you for free and open access. It has been accepted for inclusion in Dissertations and Theses by an authorized administrator of PDXScholar. Please contact us if we can make this document more accessible: pdxscholar@pdx.edu. 


\section{Creating a Learning Continuum:}

A Critical Look at the Intersection of Prior Knowledge, Outdoor Education, and Next Generation Science Standards Disciplinary Core Ideas and Practices

by

Trisha Leigh Schlobohm

A thesis submitted in partial fulfillment of the requirements for the degree of

Master of Science in Teaching

in

General Science

Thesis Committee:

William Becker, Chair

Melissa Ptter

Susan Holveck

Portland State University

2016 


\begin{abstract}
Outdoor School is a cherished educational tradition in the Portland, OR region. This program's success is attributed to its presumed ability to positively impact affective and cognitive student outcomes. Residential programs such as Outdoor School are considered to be an important supplement to the classroom model of learning because they offer an authentic, contextually rich learning environment. References to relevant literature support the idea that student gains in affective and cognitive domains occur as a result of the multi-sensory, enjoyable, hands-on nature of outdoor learning. The sample population for this study was 115 sixth graders from a demographically diverse Portland, OR school district. This study used an instrument developed by the Common Measures System that was administered to students as part of Outdoor School's professional and program development project. The affective student outcome data measured by the Common Measures instrument was complemented by a formative assessment probe ascertaining prior knowledge of the definition of plants and field notes detailing Field Study instructor lesson content. This first part of this study examined the changes that take place in students' attitudes toward science as a result of attending Outdoor School. The second part took a look at how Outdoor School instruction in the Plants field study aligned with NGSS MS-LS Disciplinary Core Ideas and Practices. The third section of the study compared how Outdoor School instruction in the Plants Field Study and students' prior knowledge of what defines a plant aligned with NGSS MS-LS DCIs. The intent of the research was to arrive at a more nuanced understanding of how students' attitudes toward science are influenced by participating in an outdoor education program
\end{abstract}


and contribute to the development of a continuum between classroom and outdoor school learning using Next Generation Science Standards Disciplinary Core Ideas and Practices as a framework. Results of this study were intended to inform outdoor education program development, add to the existing body of research, and inform future research projects. 
Table of Contents

$\begin{array}{lc}\text { Abstract } & \text { i } \\ \text { List of Tables } & \text { iv } \\ \text { Introduction } & 1 \\ \text { Literature Review } & 12 \\ \text { Methods } & 27 \\ \text { Results } & 42 \\ \text { Discussion } & 56 \\ \text { Conclusion } & 68 \\ \text { Suggestions for Improvement and Future Research } & 69 \\ \text { Reference } & 71 \\ \text { Appendix A: Outdoor School Affective Survey } & 73 \\ \text { Appendix B: Page Keeley Formative Assessment Probe } & 74 \\ \text { Appendix C: Field Notes } & 78\end{array}$




\section{List of Tables}

Table 1: Oregon Outdoor Education Coalition Collective Beliefs 2

Table 2: NGSS Science Inquiry Practice from the Framework 9

Table 3: Sample Population Demographics 29

Table 4: Outdoor School Mission Goals 33

Table 5: NGSS Disciplinary Core Ideas: Middle School Life Science 39

Table 6: Total Affective Score 43

Table 7: Paired t-test for Academic Identity and Sub-Groups 43

Table 8: Paired t-test for Motivational Resilience and Sub-Groups 43

Table 9: Sandy River Site NGSS DCI Alignment 44

Table 10: Sandy River Site NGSS Practices Alignment 45

Table 11: Camp Howard Site NGSS DCI Alignment 46

Table 12: Camp Howard Site NGSS Practices Alignment 47

Table 13: Camp Arrah Wanna Site NGSS DCI Alignment 48

Table 14: Camp Arrah Wannah NGSS Practices Alignment 49

Table 15: Summary of ODS Site NGSS DCI Alignment (with sub-categories) 50

Table 16: Summary of ODS NGSS Science Inquiry Practices Alignment 50

Table 17: Prior Knowledge as measured by the "Is it a Plant" Keeley Formative Assessment Probe

Table 18: Summary of Sandy River NGSS DCI Alignment 53

Table 19: Summary of Camp Howard NGSS DCI Alignment 54

Table 20: Summary of Camp Arrah Wannah NGSS DCI Alignment 55

Table 21: Summary of ODS NGSS DCI Alignment (no sub-categories 55 


\section{Introduction}

Every year, $6^{\text {th }}$ graders from a demographically diverse school district in Portland, OR attend a 3 day outdoor learning program known as Outdoor School (ODS) - and they are not alone. In the Fall 2014 session, 3,500 kids from 120 classrooms in this educational service district participated in this 3-6 day immersion in an alternative learning setting that takes place during their sixth grade year. The Spring 2015 session anticipates participation by over 4100 students in this educational service districtsponsored Outdoor School program. This program has been an important part of the educational culture in the region surrounding Portland, OR since 1966 and is part of a larger tapestry of outdoor education programs in the region. According to the Gray Family Foundation, a major funder of ODS in this region, about $50 \%$ of $5^{\text {th }}$ or $6^{\text {th }}$ graders in Oregon attend some kind of outdoor school for varying lengths of time. Since there are roughly 48,000 $6^{\text {th }}$ graders in Oregon, that means about 20-25,000 of these students attend some type of outdoor educational program. The belief that outdoor education programs are an essential ingredient in all students' collective educational experience is increasing in popularity. Five decades of happy campers and a growing body of research supporting this idea motivates organizations such as Friends of Outdoor School to lobby for funding to send every fifth or sixth grader in Oregon to Outdoor School or a similar program.

There is a wide variety of outdoor education programs in Oregon but their values and goals tend to align. The 2014 -15 meetings of the Oregon Outdoor Education Coalition (a statewide group of educators, businesspersons, and tribal and community 
leaders collaborating to secure funding for all Oregon students) arrived at six collective beliefs describing the importance of outdoor education:

Table 1: Oregon Outdoor Education Coalition Collective Beliefs

1. provides different way of learning and reaching multiple types of learners

2. builds healthy youth (mental, physical, emotional)

3. promotes land stewardship

4. develops leaders and opportunities for careers

5. builds empathy and relationships

6. connects kids with nature, including helping some kids overcome their fear of the outdoors

Outdoor education is not just a U.S. institution, these types of programs occur all over the world. Udeskole is a Danish, curriculum based outdoor learning program that takes place on a weekly or bi-weekly basis with children aged 7-16. It can take place in both natural and cultural settings and be used to support learning in a wide range of subjects. In a survey of Danish teachers, Benson and Sondergaard (2012) found Udeskole's greatest reported strengths to be that:

1. Progressive learning in outdoor settings adds variety and focus to existing knowledge.

2. Udeskole is school related and linked to national curriculum.

These strengths, as well as those summarized by the Oregon Outdoor Education Coalition, resonate with core values embraced by ODS (summarized in Methods, Table 2). Outdoor School is commonly regarded as being a precursor to positive changes in attitudes towards science, nature, and environmental concerns. This program is thought to 
enhance students' learning process and improve cognition in ways not experienced in a traditional classroom. While "outdoor" education removes students from their normal context and is presumed to be very different and even superior to learning "indoors", it is too often taken at face value and certainly deserves more critical evaluation (Zink \& Burrows 2008). One purpose of this study was to increase understanding of the dynamic changes in affective student outcomes (attitudes toward science) presumed to occur as a result of attending Outdoor School. Additionally, instruction in the Plants Field Study was examined for alignment with NGSS Disciplinary Core Ideas and Science and Engineering Practices. Finally, students' prior knowledge of the definition of plants was compared to Plants Field Study instructional content to ascertain how field study instruction was already building on students' prior knowledge, an important component of learning. Insights from this study were used to inform program development linking ODS curriculum with NGSS DCI's and Practices.

Outdoor School may be the first, or one of very few experiences students have in the forest, let alone a forest-situated learning environment. Here they participate in a steady stream of team building activities, outdoor games, and field study lessons. The four field studies (Soil, Water, Animals, and Plants) use an inquiry based, interactive approach to strengthen students' conceptual knowledge of natural systems and cultivate positive attitudes toward science. These Field Study lessons take place in the natural settings available at each ODS site. Just walking in the woods has been linked to improvement in focus, reasoning, and remembering (Shin, Shin, Yeoun, \& Kim, 2011). Additionally, students tend to better recall and communicate activities in which there is 
hands-on engagement, as opposed to when their role is that of passive observers (Nadelson \& Jordan, 2012).

O'Brien (2009) suggests that exploring in nature can provide a link into students' innate curiosity, providing motivation for learning and fostering curiosity, attention, and self-direction. Her study emphasized that positive changes discovered during the research process occurred because of repeated, regular contact with a natural environment, especially for children who do not normally have exposure to this kind of environment. In a study examining student outcomes of short term outdoor programs such as field trips, Prokop, Tuncer, \& Kvasničák (2007) found a significant increase in positive attitudes towards biology lessons and natural environments and that students' understanding of ecological relationships increased following participation.

Outdoor learning can be an effective way to add relevance to science by incorporating it into students' everyday lives. Repeated contact with scientific concepts in authentic scenarios can increase their general understanding of what science is. Lessons in the context of nature can also be useful for introducing students to important science concepts such as "quantitative" and "qualitative." Frissel \& Cayton (2009) used nature walks around their school to activate fourth graders observation skills and then had them sort their daily observations and measurement into the appropriate folders (qualitative or quantitative) once they returned to the classroom. The experience showed them that focusing on their local habitat and its inhabitants, students could be taught to observe, investigate, and collect data through authentic hands-on experiences. 
Fagerstam \& Blom (2012) found that students tend to talk very differently about course and content when comparing outdoor, hands-on lessons versus conventional, passive-transmittance lessons. For example students who learned outdoors tended to have much more vivid recall of their experience and were able to apply more course related vocabulary to their descriptions than students from the indoor classes.

Liddicoat \& Krasny (2014) consider memories to be as important for evaluating residential outdoor environmental education (ROEE) programs as are changes in knowledge, behavior, and attitudes. They found that students' memories are positively linked to future outdoor recreation interests, curiosity about the natural world, feelings of environmental stewardship, and can serve as a basis for social interactions. When staff and students at such a program in New Zealand were asked to describe its strengths, both groups ascribed importance to the attitudes and values needed to persevere in order to learn new skills, live in group housing, build relationships, and adopt feelings of responsibility towards assigned tasks. Many students had vivid memories of fun generated during the times in-between activities and felt these new bonds had the potential to last a lifetime (Zink \& Burrows, 2008). The contextually and emotionally rich nature of outdoor education has been associated with increased retention and recall. Positive emotional experiences tend to create vivid, life shaping memories and put a positive tilt on education, leading to an increased likelihood of lifelong interest in learning (Liddicoat \& Krasny, 2014). When asked to recall their most vivid childhood memories, Waite (2008) found that the majority of adults recalled informal educational settings and these memories often mentioned the presence of a more experienced 
adult. ODS roots their program in the meaningful, informative interactions taking place between students and knowledgeable, well-trained staff and student leaders.

While the Outdoor School staff places great value on enjoyment and close attention to content, one of the program's great strengths is its high level of organization. The day to day schedule at all Outdoor School sites is unified for consistency and to ensure all students optimal exposure to the emotional, social, and educational benefits of the program. In their study of field trips Nadelson \& Jordan (2012) contend that the pedagogical benefits of these experiences may be more strongly influenced by how they are organized and presented to students than by actual content. Their research supported that organizing a trip in a way that gave students the opportunity to apply their existing knowledge in novel, hands-on ways increased their interest, engagement, and enjoyment associated with the trip's activities. These are factors commonly associated with increased retention of knowledge and memories of events.

Participation in well-planned outdoor education programs can lead to increased knowledge of and more positive attitudes towards biology. Fancovicova \& Prokop (2011) found a significant increase in knowledge concerning plants after participation in a botany-focused outdoor learning program. Additionally, proportion of participants who reported biology as their favorite subject strongly increased after participation in the outdoor program.

Muscat \& Pace (2013) stress that informal learning environments have the potential to address a wide range of learning styles and personal interests as well as present learning as a lifelong process. Site visits are a means of connecting students to 
relevant, concrete experiences that offer scientific learning in contextualized, topic specific environment. These experiences can serve to strengthen understanding of concepts and increase students' ability to apply these concepts and reasoning to new, real life situations. In post-visit interviews, students indicated that they had appreciated the extra detail provided by the site visit and that the in-person experience had broadened their knowledge and ability to understand and discuss biological concepts in a more in depth way. The authors stressed that these positive results occurred for all students, as opposed to a minority already showing a predilection towards science. In order to provide an optimal outdoor classroom for students of all backgrounds and learning propensities, the Outdoor School program places emphasis on creating an environment where all students' emotional needs are met and enjoyment is part of learning. Supporting these basic psychological needs is considered a crucial part of fostering the engagement and resilience necessary for students to be successful in STEM (science, technology, engineering, \& math) courses and careers (Saxton, et al., 2014).

The Portland Metro STEM Partnership (PMSP) identifies "academic identity" and "motivational resilience" as essential psychological precursors for engagement and success in STEM college majors and careers. Academic identity (AI) is defined as "students' deeply held views of themselves and their potential to enjoy and succeed in STEM classes and careers.” AI is further broken down into: identity, belonging/relatedness, competence/efficacy, autonomy/ownership, and purpose. Motivational resilience is defined as "enthusiastic hard work and persistence in the face of challenging STEM coursework" and has two sub-components: academic engagement 
and constructive coping. Students possessing these qualities could be described as having the persistence, or grit, to meet challenges and succeed in the face of difficulty. Outdoor School strives to provide students with both the learning challenges and necessary support system to strengthen their problem solving skills and enable them to approach new situations with curiosity and confidence.

In addition to using inquiry to develop students' appreciation and knowledge of natural resources and the systems they are a part of, outdoor learning scenarios can help students can develop skills in language, mathematics, team-work, art projects, etc. Constructivist learning, strengthened by social and physical experiences, can benefit wide range of students, including autistic children and those with other behavioral and emotional challenges (O’Brien, 2009). Outdoor School provides extra services to students with special physical, emotional, and/or academic needs. Volunteers and specially trained staff strive to ensure that all students can be active participants in all Outdoor School activities. Many consider supplemental programs such as Outdoor School necessary for addressing the diverse learning styles and needs of such a large and diverse student population. Unfortunately, like many supplemental and after-school programs, Outdoor School is threatened by economic challenges. What used to be a week long program for all students, is now a 3-day trip for most students. In general, more affluent schools get the full, 6-day version and most public schools get the lite, 3-day version. Some schools have been forced to opt out entirely. ODS narrowly escaped being shut down completely in 2012. There is little doubt as to the beneficial nature of these programs but without research supported evidence of student gains they remain at risk for more cutbacks and 
even elimination. Well-documented research into student outcomes in outdoor learning programs such as Outdoor School is crucial for informing policy decisions that dictate their future as part of the wider educational system. Existing research points to significant positive gains in cognitive and affective domains and these changes can occur in a wide variety of outdoor settings and time frames.

Untangling the connections between the cognitive and psychological aspects of outdoor education is fertile ground for the academic research integral to developing effective educational approaches specific to the outdoor learning environment. Additionally, connecting Outdoor School to classroom learning using Next Generation Science Standard Disciplinary Core Ideas and Science and Engineering Practices as a framework has strong potential for optimizing the continuum of learning between these two settings.

The Next Generation Science Standards (NGSS) have been developed by the National Research Council (NRC), the National Science Teachers Association, the American Association for the Advancement of Science, and Achieve. The NGSS is adapted from A Framework for K-12 Science Education, a publication grounded in the most current science research in science and science learning. The Framework identifies the most important science that K-12 students should know and the NGSS organizes this content into three interconnecting dimensions: Practices, Crosscutting Concepts, and Disciplinary Core Ideas.

"Practices" in this context refers to the behaviors scientists engage in as they investigate the natural world and construct models and theories that reflect collective 
gains in understanding, as well as the key set of practices engineers engage in as they design models and systems. These practices are commonly referred to as, respectively, scientific inquiry and engineering design. To further clarify, scientific inquiry involves the formulation of question that will be answered through the process of investigation, while engineering design formulates a problem that will be solved through design. This study focused on the Science Inquiry practices because, at this time, including engineering design in the curricuculum is not an explicit goal of the Outdoor School program in this study. The eight Science Inquiry Practices identified by the Framework and embraced by the NGSS are listed in Table 2 .

Table 2: NGSS Science Inquiry Practice from the Framework

\begin{tabular}{|l|}
\hline 1. Asking questions; \\
\hline 2. Developing and using models; \\
\hline 3. Planning and carrying out investigations; \\
\hline 4. Analyzing and interpreting data; \\
\hline 5. Using mathematics and computational thinking; \\
\hline 6. Constructing explanations; \\
\hline 7. Engaging in argument from evidence; \\
\hline 8. Obtaining, evaluating, and communicating information. \\
\hline
\end{tabular}

"Cross-cutting Concepts" are concepts that can be applied across all domains of science. Patterns, similarity, and diversity; Cause and effect; Scale, proportion and quantity; Systems and system models; Energy and matter; Structure and function; 
Stability and change are all NGSS Cross-Cutting Concepts that can be taught in a variety of science subjects. These concepts are intended to form a coherent infrastructure for learning science and appreciating its universal relevance. Cross-cutting concepts' relation to science subject matter should be made explicit to students throughout all grade-bands in order to emphasize the interconnectivity and wide applicability of these concepts.

"Disciplinary Core Ideas (DCIs)" are grouped into four domains - the physical sciences; the life sciences; the earth and space sciences; and engineering, technology and applications of science. The DCIs for have enormous potential for focusing science curriculum and creating direction for instruction and assessment. The Framework lists four criteria with which DCIs should ideally align - they should: be applicable across many grade levels, increasing in complexity and sophistication as students move through grade bands; be relatable and relevant to students; useful as conceptual tools for increasing understanding of more complex ideas and solving problems; or be broadly important across diverse sciences or engineering disciplines or be a key organizing concept of a single discipline.

By exploring connections between prior knowledge, affective changes, NGSS DCIs and Practices, and outdoor education, this study sought to illuminate the relevance of the local Outdoor School program to the gestalt of student learning while contributing to the broader body of research.

This study proposed three questions: 
The first research question examined the changes occurring in students' attitudes concurrent with attending outdoor school:

1) How are student attitudes toward science affected by attending Outdoor School?

Data used to measure changes in ODS students' motivational resilience (MR) and academic identity (AI), as well as their subcomponents, was collected as part of a 20142015 project administered by ODS as part of a program to inform professional development of instructional staff. These changes were measured by a pre-post, student self-report survey developed by STEM Common Measurement System.

The second research question examined alignment of the Plants Field Study introductory instruction with NGSS Disciplinary Core Ideas and Practices.

2) To which NGSS Disciplinary Core Ideas and Practices does introductory instruction in the Plants Field Study align?

Field notes detailing Plants Field Study introductory instructional content provided context for this comparative examination. These field notes were crossreferenced with NGSS Middle School Life Sciences DCIs and the first five of the NGSS Science Inquiry Practices previously listed in this section.

The third research question compared NGSS DCI alignment between students' prior knowledge and Plants Field Study introductory instructional content. 
3) How does Plants Field Study NGSS DCI alignment compare to student prior knowledge NGSS DCI alignment?

Prior plant knowledge was measured using a Page Keeley formative assessment probe (“Is it a Plant?"). Scores were assigned based on how many student responses aligned with 18 emergent response themes.

To measure alignment with NGSS MS-LS DCIs, the emergent themes from the Keeley formative assessment probe were compared to the NGSS MS-LS DCI's to ascertain which student responses could be easily connected to the aforementioned NGSS standards. "Easily" in this context means that the concepts require minimal explanation to establish connection. For example, a student response of "photosynthesis" is "easily" relatable to MS-LS1 because DCI LS1.C states that: "Plants, algae (including phytoplankton), and many microorganisms use the energy from light to make sugars (food) from carbon dioxide from the atmosphere and water through the process of photosynthesis, which also releases oxygen. These sugars can be used immediately or stored for growth or later use." This process resulted in a total score measuring how many of each student's responses aligned with NGSS MS-LS1,2,3, and/or 4.

Both prior plant knowledge and field instruction were compared to NGSS MS-LS DCIs to establish a general idea of how closely student prior knowledge and ODS are already aligning with these DCIs and provide data that may be used to inform development of a curriculum continuum between indoor and outdoor learning in this context. 


\section{Literature Review}

The body of literature offers a multi-faceted, ever-growing view of outdoor education as it exists all over the world. The environments and operatives of these programs can be wildly different but the mechanisms that power changes in attitude, cognition, and other student outcomes may be relevant and applicable across a wide spectrum of outdoor learning programs. Recognizing that outdoor learning deserves a closer look and should not be considered isolated from indoor, or classroom learning, is the first step in developing a theoretical framework for maximizing its benefits. To truly move forward with an effectual plan to optimize learning in the indoor-outdoor continuum, we need an informed view of how desirable student outcomes such as deep understanding of content, retention, and recall come about. The next logical step is gaining understanding of how outdoor education functions in its three basic forms: as part of the regular curriculum, as residential programs, and as field trips. To ensure that gains made in understanding these mechanisms contribute to future program success and development, we need ways to evaluate these dynamic changes theorized to occur in outdoor education. As our understanding of how learning occurs beyond the classroom grows, connecting to research-based, thoughtfully constructed education standards is vitally important for putting all the pieces together into a framework that provides a userfriendly guide for implementing a strategy to connect indoor and outdoor learning.

\section{The Nature and Theory of Outdoor Learning}

Learning "outdoors" is presumed to be very different from and even superior to learning "indoors". Outdoor education is generally assumed to be a place of 
transformative, authentic experience because it removes students from their normal context. Zink \& Burrows (2008) looked at how these how these assumptions come about and are sustained. For example, outdoor education may not be good for everyone. This study focused on a residential outdoor program attended by 400 students, aged 11-18, from an all-girls secondary school in New Zealand. The researchers interviewed students (number not specified) at the end of each camp session and two camp instructors at the end of the year. The instructors tended to place value on the "real" feedback it offered the students and how consequences were more meaningful in the outdoor context than in a classroom setting. When the students were asked about their experiences and perceptions about camp, some commented that that they felt they had more responsibility than at school and had more opportunities to make decisions. The enjoyment aspect of the outdoor program was a prevailing theme and many students felt they had learned things. However, it was unclear to the authors what the students had learned or if the lesson was unique to an outdoor setting. Given the ambivalence of student responses, the authors challenged the generally unquestioned benefits of outdoor learning. The stance that Zink and Burrows took is that popular notions of what outdoor learning is and involves is too often taken at face value and needs to be more critically evaluated - that the experiential knowledge students bring to this new context from their normal "indoor", and familyrelated lives should not be ignored when evaluating outdoor education. They felt that students shouldn't be considered blank slates upon beginning an outdoor program. The authors concluded that thoughtful investigation into the mechanisms of learning and personal growth in both environments will lend greater insight into the flow of experience between the two and into what is presumed to work and what is actually 
happening. Increased research into outdoor learning is needed for a clearer understanding of the strengths and shortcomings of these programs. Insights from all over the world have the potential to contribute to the developing theoretical framework of outdoor education.

$14 \%$ of Danish schools integrate some kind of outdoor education, or Udeskole, into students' normal educational experience. Udeskole is curriculum based outdoor learning that takes place on a weekly or bi-weekly basis with children aged 7-16. This program can take place in both natural and cultural settings and be used to support learning in a wide range of subjects that are introduced in an authentic, relevant, and often cross-disciplinary setting. Udeskole, however, is not mentioned in the national curriculum and knowledge of how this kind of learning works is poorly understood. This lack of informed perspective into the nature of learning in outdoor settings inspired Benson and Jensen (2012) to examine the tensions that exist at the various levels of curriculum development, implementation, and ultimately learning at the student level. The authors developed a 50 question survey that asked teachers to describe various aspects of their approach to outdoor learning. 216 individual teachers from 178 school responded. They found Udeskole to be a functional addition to normal curriculum in that progressive learning in outdoor settings adds variety and focus to existing knowledge and that Udeskole is school related and linked to national curriculum. Problems with Udeskole were that: teaching practice is highly variably between teacher, time, and place; it is not practiced across all subjects as recommended; participation decreases in frequency as grade level increases; and it is practiced mainly in green spaces, but 
recommended for a variety of locations and environments. In summary, the authors found that, in practice, Udeskole theory is highly variable, as a result of adaptation and implementation specific to teacher motivation and educational environments. To optimize Udeskole's potential as an effective supplement to the national curriculum, authors proposed that: 1) outdoor teachers expand their practice and include all subjects and grade levels, as well as including a wide range of outdoor learning environments, 2) curriculum development and reflective planning at multiple levels in the education system, as well 3) continuing training and professional development of teachers in special regards to outdoor learning. Developing a unified approach to outdoor education that builds on its strengths and focuses on developing effective pedagogies requires a functional understanding of how the desired student outcomes come about in the first place - memories, for example, are unquestionably important by why do these programs tend to leave such vivid impressions? Perhaps it is the positive emotional experiences associated with outdoor learning that create such vivid, life shaping memories - the ones that can put a positive tilt on education and lay the groundwork for future interest in lifelong learning.

In a study investigating the qualities of adult and child memories Waite (2007) began with a discussion about the physiological pathways of memory and how the emotional content of experiences could serve to increase retention and recall. Her research used data collected from surveys sent to various learning settings in Devon, England. Two sets of surveys were sent out, one to settings with children aged 2-5 and the other with children aged 6-11. In addition to staff members, 18 children, aged 8-11, 
were interviewed during the case studies. These surveys asked staff about their values and attitudes towards education outdoors, current outdoor learning programs, and perceived obstacles to continuing and improving these programs - 334 responses were received. Their responses were transcribed and emergent themes analyzed. The author focused in on one survey question: 'Please describe in detail a memory you have from your childhood of a significant experience in an outdoor setting? Include details such as the type of environment, the level of enjoyment, things you learnt etc.' Using data collected from the survey and five case studies involving a child-minder, pre-school, private nursery, foundation stage and primary school, the author attempted to tease out what it is about outdoor experiences that make them so memorable. Authenticity, active investigation and challenge were the dominant themes children's descriptions. Adult responses also highlighted "real-life", or authentic experiences and a majority of their responses related memories formed in "informal" learning setting. Both child and adult responses indicated autonomy and "interest-led" learning to be significant to their memorable experiences. Because of the clarity of the memories and that these memories were made away from traditional classroom settings, both child and adult responses were interpreted by the author to support the need to develop alternative pedagogies for optimal outdoor learning. In addition to the emotional and contextual qualities of memory formation, just being in contact with natural settings might improve learning and attitudes. There is a growing body of evidence that interaction with nature has a beneficial effect on general well-being and cognitive function. 
The propensity of natural landscapes to reduce mental fatigue is attributed to the absence of attention-commanding stimuli that is a constant factor in modern, urbanized environments. Contact with nature is purported to garner physiological benefits that include lower blood pressure and pulse rate. Shin, Shin, Yeoun, \& Kim (2011) found that people who took walks in the forest performed better on a cognitive test measuring attention, sequencing, visual scanning, and executive mental function (Trail Making Test B). People taking the same length walk in a busy urban setting did not experience these benefits. Those walking in the forest also experienced psychological benefits indicated by lower levels of anxiety, depression, confusion, and anger (Profile of Mood States Test). Conversely, their moods changed in a negative way when they walked downtown. The subjects of this study were 60 students from a four-year university in South Korea. 35 males and 25 females (average age 23.27 years) made up the test population. All participants took 50-55 minute walks in both forested and urban locales one week apart. The authors saw these results as promising in regards to using the forest as a tool for positively influencing both cognitive and affective outcomes of subjects. They feel it further validates existing research into the restorative and psychological benefits of time spent in natural settings.

Natural settings are gaining appreciation as optimal settings for learning in a variety of subjects, science in particular. They are associated with improved memory formation, cognitive ability, and attitude. Nonetheless, there is much to be learned about the nuances of this educational approach. The next section discusses outdoor education as part of the regular curriculum, as field trips, and as residential programs. Common 
themes throughout are: improved recall and conceptual understanding, improved attitudes towards science and natural systems, improved concentration, and increased feelings of environmental stewardship and social confidence in participants.

\section{Outdoor Learning as Part of the Regular Curriculum}

Outdoor learning can be an effective way to add relevance to science by incorporating it into students' everyday lives. One place this integration can occur is as part of their regular school curriculum. Fagerstam \& Blom (2013) focused on an outdoor teaching intervention in a Swedish urban high school that was attempting increase learning in outdoor settings and, in turn, investigate possible effects on student health and learning outcomes. The authors evaluated student outcomes using a combination of essays and interviews. The following questions guided their research: 1) What are the long-term effects of outdoor teaching in biology on high school pupils' knowledge of ecology and classification?, and 2) What are high school pupils' attitudes towards learning biology and mathematics outdoors compared with indoor teaching? The study population consisted of two classes from seventh grade, 13 to 14 years, and two classes from eighth grade, age 14 to 15 . One class from each grade participated in an outdoor centered Biology curriculum, while the other learned mostly indoors. The total test population was 88 students. Their first method of data collection was an essay-type question concerned with the biology course content that was given to the students two weeks into the course and then again six months after the course ended. The second method used semi-structured interviews given five months after the course to examine student attitudes about learning in an outdoor setting. Statistical analysis of the essay-type 
questions did not reveal any significant differences in understanding in either grade but the authors noticed that outdoor class students were more likely to use specific examples of organisms as ways of explaining classification systems. In the interviews, students from the test and control classes described their experiences quite differently, with outdoor class students using more course-related words and providing more vivid, contextually detailed descriptions. Another trend discovered during the interviews was that the outdoor students more clearly recalled the course content, used more contentrelated vocabulary in their responses, and described a participatory experience. This contrasted with the primarily teacher-oriented, often vague responses of the indoor class. All pupils in the outdoor sample related a positive opinion of their experience and appreciated the variety, hands-on learning, and interaction aspects of outdoor learning.

Outdoor programs are considered to be valuable supplementation to traditional Biology curriculum but the changes in attitude, knowledge, and environmental behavior that are assumed take place in these learning environments are poorly understood. Additionally, studies measuring student knowledge and perceptions of plants are largely absent. In an attempt to see if a botany-focused outdoor learning program could counteract "plant blindness", Fancovicova \& Prokop (2011) looked at students' attitudes towards and knowledge concerning plants before and after participation. The experimental group took part in an annual tree-planting project that takes place during May \& June. Their study population consisted of fifth graders (ages 10 and 11) from one urban school. They were divided into a quasi-experimental and a control group. Each group consisted of 17 students for a total sample population of 34. Both groups 
participated in outdoor learning programs but only the experimental group focused on practical work with plants and plant ecology. Students received pre-tests ( 2 days before program began), post-tests ( 3 days after program ended), and re-tests ( 3 months after program ended) to measure changes in knowledge and attitudes regarding plants that resulted from their participations in the outdoor program. Attitude was measured using the Plant Attitude Questionnaire (PAQ). Knowledge of plants was measured using a test containing open-ended questions, assignment questions, multiple-choice questions, additive questions to complete a food web scheme, and a question relating to drawing a meadow ecosystem. The study showed that outdoor education programs can positively influence pupils' attitudes towards plants and the authors stress that this is the first experimental evidence used to show planting trees improves pupils' views of plants. Student knowledge of plants was also revealed to be positively influenced by outdoor educations programs, further supporting the importance of outdoor learning in regard to plant awareness.

Outdoor learning can integrate and strengthen cognitive, emotional, and social behaviors. O'Brien (2009) found that Forest School (a widespread outdoor education program in Britain, Scotland, and Wales) improved participants' social skills, motivation and concentration, and new perspectives. Her research used a three stage process involving a workshop of practitioners, on-site data collection of practitioners, and a reflection workshop. Data collection involved two phases of case studies in Wales and England. Twenty-four students, aged three to nine years, in addition to teachers and Forest School leaders, were chosen to participate in the study. She emphasized that 
positive changes discovered during the research process occurred because of repeated, regular contact with a natural environment, especially for children who do not normally have exposure to this kind of environment. Participating schools send students to Forest School for morning or afternoon sessions that can occur weekly or biweekly and can run anywhere from 2 to 12 months. At Forest School the children can get involved in a wide range of activities. They might use tools to create artwork or listen and respond to stories as a way to improve language and communication skills. Learning about habitats, plants and animals, as well as working in teams so they can learn to take turns and share, are also part of Forest School sessions. The range of improvements supported by these case studies provide support for the practicality of Forest School becoming embedded in the normal routines of many schools. It could benefit students who don't normally have access the outdoors as well as a wide range of students, including autistic children and those with other behavioral and emotional challenges.

Cayton \& Frissell (2009) used school-yard ornithology as an anchor for introducing a wide variety of science concepts and practices to their students over the course of a school year (9 months). The length and depth of this project gave students a chance to apply science concepts and investigate their subject in great detail, meanwhile developing their inquiry skills and learning how to connect to the community. The time spent describing their subject expanded students' vocabularies while also strengthening their reading and writing skills. An initial stage of the project helped them learn the difference between qualitative and quantitative date and their understanding of this difference grew throughout the project. Their bird-watching helped the students become 
more familiar with and connected to their immediate environment, which resulted in greater concern for and curiosity regarding its inhabitants. Connections were made between what the students learned in the classroom about how ecosystems work and what they could observe in the schoolyard and on field-trips. Students were introduced the National Wildlife Federation website, which has many resources for students. The students used the website to create a schoolyard garden that was eventually certified as a NWF habitat. They further synthesized their learning throughout the year into a Web of Life exhibit at the State Fair, and transformed their classroom into a virtual wildlife museum with a multitude of educational stations that opened to the public (parents, administrators, classes, local experts, etc.) for two days. This authentic, hands-on experience engaged students on multiple levels while maintaining focus and can facilitate integrative learning in an enjoyable way. Student learning was assessed in a variety of ways, including journal writing and reflections.

Integrating outdoor learning into students' regular curriculum represents an educational ideal and one that can lend emotional and contextual richness and variety to a wide range of subjects and learning abilities. It can be a way to offer frequent exposure to natural and cultural settings and maximize the theorized benefits of outdoor learning contexts. The repeated contact with subject matter necessary for deep conceptual understanding supports the development of a NGSS DCI and Practice-based continuum between the classroom and outdoor educational programs. Operating on the other end of the spectrum are field trips, short but potentially powerful learning tools. Understanding what works during these excursions can inform planning across a wide range of outings 
and may also provide valuable insights into program implementation in other types of outdoor education.

\section{Field Trips as an Educational Tool}

Muscat \& Pace (2013) investigated the potential of field trips to strengthen a wide range of students' in-depth understanding of biological concepts. Their study built on the premise that reform is needed in science curriculum and new means of delivery are necessary to reach larger populations of students. Their introduction stressed that informal learning environments have the potential to address a wide range of learning styles and personal interests as well as present learning as a lifelong process. The authors contend that field trips are an effective means of connecting students to relevant, concrete experiences that offer scientific learning in contextualized, topic specific environment. This is because these experiences can connect students' existing knowledge to new context-dependent examples, thereby strengthening understanding of concepts and increasing their ability to apply these concepts and reasoning to new, real life situations. The test population consisted of eighteen high school students, all 16 years old. The research methodology involved meta-cognitive tools (Vee diagrams and concept mapping), as well as class discussions and interviews. The sites visited were a greenhouse and a blood bank and were chosen in regard to topics already being addressed in their classrooms, "nutrition in plants" and "transport in humans". Notable results were that students came to recognize out-of-classroom activities as viable ways to gather information and appreciate the relevance of careers and processes to which they had previously given little thought. Students became newly aware of various functions the 
facilities served as well as the human aspects of such operations. They also reported finding the visits interesting and helpful for remembering topics. When examining postvisit concepts maps and Vee-diagram questions, the researchers discovered that new concept details, examples, and connections were added while misconceptions and unnecessary statements tended to disappear. In post-visit interviews and class discussions students indicated that they had appreciated the extra detail provided by the site visit. Students also felt the in-person experience had broadened their knowledge and ability to understand and discuss biological concepts in a more in depth way. The authors stressed that these positive results occurred for all students, as opposed to a minority already showing a predilection towards science. Also underlined was the importance of carefully planning the site visits to ensure an atmosphere of meaningful learning that connects to and reinforces classroom learning.

The movement towards an inquiry-based, student centered approach to learning about natural systems can build on students' natural interest in science. A wide range of previous research supports the positive effects of long term outdoor learning on attitude and cognition but time, seasonal, and financial restraints make spending more than a day in the field impractical. Field trips can be an excellent way to give learning "real life" value and may be the most attainable option for outdoor learning in many situations. Unfortunately, field trips are frequently held in low-esteem by educators due to logistical challenges and their influence on student outcomes considered are poorly understood. Prokop, Tuncer, \& Kvasničák (2007) sought to bridge this gap in knowledge by investigating the effects of short-term experiences in the field on student attitudes and 
knowledge towards biology. The test population was composed of 143 sixth graders (11/12 years old) from one urban and two rural schools. They were randomly divided into experimental and control groups, each consisting of one class from the urban school and one from the rural school. Tests measuring opinion of favorite subject, interest in animals and plants, and experiences in field trips administered two months prior to the treatment showed no differences between experimental and control groups. The experimental group took a one day field trip that focused on ecology in the field, visiting three different ecosystems. The control group did not attend the field trip, instead they attended a traditional biology lecture. Pre- and post-tests measuring attitude and knowledge were administered to both groups one month before and three days after the trip. The experimental group showed a significant increase in positive attitudes towards biology lessons and natural environments and while the control group was unaffected. Knowledge was measured using a two-tier multiple-choice test and drawing in combination with open-ended questions. The multiple choice test indicated that the experimental group displayed a significant increase in biology knowledge and the drawing/open-ended questions showed that students' understanding of ecological relationships had increased. Significant changes were not found for the control group.

Field trips can give students the valuable opportunity to apply content they've learned in the classroom to situations outside the school environment. This hands-on learning is likely to improve their conceptual understanding and retention of knowledge because it gives students an opportunity to transfer existing knowledge to and anchor it in a real life context. There is research that supports this idea but expands on it by 
suggesting that the organization of these field trips can be just as, if not more, important than the subject content of these experiences. How students experience the intended "lessons" can have a huge impact on attitude towards and retention of knowledge. Nadelson \& Jordan (2012) explored what influence the format and content of field trip activities had on student attitudes toward the events of the field trip and how it influenced student recall. They felt that students had learned from the experience if they were able to recall activities from the field trip a month later; and that this kind of information could be used to provide context for investigating student learning on field trips. The authors' data collection method allowed students to freely communicate their recollection of even using both writing and drawing. Their study focused on a variety of environmental education activities taking place in a local park during an event staged specifically for the research project. Participants were 111 sixth graders. Data collection was delayed for a month after participation in the outdoor program. Student responses indicated an overall positive attitude towards the experience and that these attitudes were more associated with program content than just social aspects. The hands-on activities were recalled much more frequently than events in which students were passive observers. This was felt to indicate the importance of integrating physically engaging activities into field trips and other outdoor learning programs. Overall, they found that participants' recall of events was tied to a combination of both activity format as well as content and that this kind of information should be used to inform future field trip design and assessment. 
Field trips, while relatively brief, can be incredibly effective with thorough and thoughtful planning. They can be used to expose students to many different ecosystems, careers, and concepts. They can be used to add relevance to students' preexisting knowledge and refine what they've learned in the classroom. Residential programs are a longer-term form of outdoor education that, due to the length and intensity of the programs, are considered to have deep and lasting cognitive and affective impacts on participants. The memories people relate from residential outdoor education experiences are often quite detailed and even influence attitudes and behavior throughout their lives. These memories may have the potential to serve an evaluative purpose and complement other evaluative frameworks such as the STEM Common Measures System affective surveys used in this research project.

\section{Residential Programs and Evaluation}

An emphasis on memory creation and future use of these memories could maximize the long term impact of these programs. The implicit goals of these programs are generally to create feelings of empathy and empowerment towards environmental issues and the social concerns connected to them. Less is known about how participants later build on this increased knowledge of and more informed attitudes toward natural systems. Liddicoat \& Krasny (2014) examined the value of residential outdoor environmental education (ROEE) programs in creating autobiographical episodic memories. They were interested how people interpret their experience use these vivid memories in the long term. The authors hoped their research might inform creation of a theoretical model for using memories as a measure of program outcome. They conducted 
interviews with 54 teens five years after participation in one of two residential outdoor environmental educations (ROEE) programs. These programs took place at either "Mountain School" in North Cascades National Park, or the "Teton Science Schools" program in Grand Teton National Park. Both programs were three day camping trips for fifth graders. Analysis of the interviews revealed a variety of post-program applications for their ROEE memories that included: participating in outdoor recreation activities, having more knowledge of and appreciation for local ecology, engaging in environmentally responsible behaviors, and reminiscing with friends about the experience. For example, participants reported recalling and using knowledge of local flora and fauna gained during their experience, as well as increased feelings of environmental stewardship. The likelihood of these memories to influence future behaviors and even influence future career decisions adds value to these memories' potential as evaluative tools. Complementing the potential use of memories as evaluative tools for outdoor education is the development a Common Measurement System for STEM (science, technology, engineering, and mathematic) education. This Common Measurement System is being developed by the Portland Metro STEM Partnership (PMSP) in Oregon. There is currently a project adapting these common measures for use in outdoor education programs.

Saxton, et al. (2013) identified the need for a system of common measurement for K-12 STEM education that considers career and college readiness, teacher practice, and measurement strategies for programs and systems. Weaknesses of the current model of educational evaluation include student underperformance (NAEP, and TIMSS scores), 
shortfalls in teacher practice (isolation of STEM concepts, emphasis on rote memorization, and neglect of higher order thinking skills. The authors conceptualized a model for developing and implementing a system that will lead to reliable ways to pinpoint problems and connect the different domains of education. The Common Measures System's theory of change is based on a systems model of interconnections involving school-level support, professional development, educator practice, and variables impacting student learning; it will emphasizes collective impact and diverse perspectives. The STEM Common Measures System will develop ways to evaluate student outcomes (higher order cognitive skills, academic identity, and motivational resilience), teacher attributes (pedagogical content knowledge, instructional practices, and self-efficacy), as well as school level supports such as collective teacher efficacy and transformational leadership.

This literature review provides rationale for this thesis by illustrating how effective outdoor learning can be used to complement students' normal education. Connecting outdoor learning to classroom curriculum in purposeful, thoughtful ways has the potential to bolster a learning continuum that makes optimal use of prior knowledge, affective gains, repeated exposure to science concepts, and authentic educational experiences. The benefits of outdoor learning can occur during normal school hours as part of the normal curriculum, as field trips, or as residential camping experiences. These programs can address a wide range of learning styles and support an interest in lifelong learning. At a time of worldwide revamping of educational systems, further research into the pathways of learning are important in the development and implementation of these 
programs. All the articles in this review function in establishing a need for critical and thoughtful evaluation of how learning occurs in these kinds of environments. 


\section{Methods}

This study proposed three questions:

1) How are student attitudes toward science affected by attending Outdoor School?

2) To which NGSS Disciplinary Core Ideas and Practices does introductory instruction in the Plants Field Study align?

3) How does Plants Field Study NGSS DCI alignment compare to student prior knowledge NGSS DCI alignment?

\section{Overview}

The first research question employed a quasi-experimental, pre-test/post-test design. This question explored quantitative changes occurring in students' attitudes that may be occurring as a result of attending outdoor school. Data used to measure changes in ODS students' motivational resilience (MR) and academic identity (AI), as well as their subcomponents, was collected as part of a 2014-2015 project administered by ODS as part of a program to inform professional development of instructional staff. These affective surveys were administered to students two weeks before and two weeks after their ODS experience. Changes in students' motivational resilience (MR) and academic identity (AI), including subgroups, were measured by a pre-post, student self-report 
survey developed by STEM Common Measurement System and adapted for Outdoor School.

Academic Identity is defined by the Portland Metro STEM Partnership (PMSP) as: students' deeply held views of themselves and their potential to enjoy and succeed in STEM classes and careers. This definition of AI encompasses four subgroups: belonging/relatedness, competencelefficacy, autonomy/ownership, and purpose. The Outdoor School project added a fifth AI sub-group, identity, which measures how students see themselves succeeding in STEM and using it in their future careers. "Motivational resilience" is defined by PMSP as: enthusiastic hard work and persistence in the face of challenging STEM coursework. This definition of MR encompasses two subgroups: academic engagement and constructive coping.

The second question examined and qualitatively evaluated the alignment between introductory instruction in the Plants Field Study and NGSS Middle School Life Science Disciplinary Core Ideas and Practices. Field notes detailing Plants Field Study introductory instructional content provided context for this comparative examination. To measure Plants Field Study introductory instructional alignment with NGSS MS-LS DCIs, detailed field notes of this instruction were compared to the NGSS DCI's to ascertain what instructional content could be easily connected to the aforementioned NGSS standards.

The third research question qualitatively compared NGSS DCI alignment of students' prior knowledge and Plants Field Study introductory instructional content. Prior knowledge of what defines a plant was measured using a Page Keeley formative 
assessment probe (“Is it a Plant?") to assign scores based on how many student responses aligned with 18 emergent response themes. Field notes detailing Plants Field Study introductory instructional content provided the complementary data for this qualitative analysis.

Data collection took place during Outdoor School's 2015 spring session (typical sessions last seven weeks). Affective survey ("Attitude toward Science") and prior knowledge ("Is it a Plant") data used to answer the research questions \#1 and \#3 came from 115 sixth graders from a demographically diverse Portland-area school district. Field notes used to answer questions \#2 and \#3 were collected at three ODS sites during the Spring 2015 session. These field notes detailed introductory instructional content presented to visiting students by lead instructors in the Plants Field Study at all three ODS sites.

\section{Participants}

The sample for this study consisted of 115 sixth graders from a demographically diverse, low SES (socio-economic status) public school district in Portland, Oregon. The students came from three middle schools in this district. An average of $79 \%$ of the students from these three middle schools qualify for free or reduced lunches. The sample of students from these schools included sixth graders from these schools who attended Outdoor School during the Spring 2015 session and who took both the Keeley probe (prior knowledge) and the pre-post affective surveys - no other selection criteria was applied. 
Table 1 shows the 2014 demographics reported by these schools in this district.

Minority attendance exceeds $50 \%$ at all three schools and an average of $79 \%$ of students at these schools qualify for reduced or free lunches.

Table 3: Sample Population Demographics

\begin{tabular}{|l|l|l|l|l|l|l|l|l|}
\hline $\mathbf{2 0 1 4}$ & Hispanic & $\begin{array}{l}\text { Native } \\
\text { American }\end{array}$ & Asian & Black & $\begin{array}{l}\text { Pacific } \\
\text { Islander }\end{array}$ & White & Multi & $\begin{array}{l}\text { Reduced/ } \\
\text { Free } \\
\text { Lunches }\end{array}$ \\
\hline $\begin{array}{l}\text { School } \\
\# \mathbf{1}\end{array}$ & $18.3 \%$ & $0.3 \%$ & $15.8 \%$ & $8.0 \%$ & $1.1 \%$ & $49.6 \%$ & $6.9 \%$ & $73.8 \%$ \\
\hline $\begin{array}{l}\text { School } \\
\# \mathbf{2}\end{array}$ & $30.3 \%$ & $0.4 \%$ & $10.8 \%$ & $10.1 \%$ & $0.3 \%$ & $41.3 \%$ & $7.0 \%$ & $77.8 \%$ \\
\hline $\begin{array}{l}\text { School } \\
\# 3\end{array}$ & $26.2 \%$ & $1.0 \%$ & $16.3 \%$ & $13.5 \%$ & $1.0 \%$ & $36.9 \%$ & $5.1 \%$ & $85.6 \%$ \\
\hline
\end{tabular}

\section{Treatments}

The treatment in this study (Question \#1) was the students' learning experience at Outdoor School. Outdoor School has been part of the educational culture in Oregon since 1966. Every year, approximately 7000 sixth graders from the region surrounding Portland, Oregon partake in this highly anticipated residential program. ODS takes place during two 7-week "sessions", one taking place in the fall and the other in the spring. Students take a 3-, 4-, or 6-day excursion to one of several of ODS sites chosen for their easy access to absorbing, hands-on learning in the beautiful Pacific Northwest backdrop. The sample population for this study only attended the 3-day program and only field notes taken during the 3-day program were used in this study. The ODS curriculum employs an inquiry based approach designed to shed light on the natural processes behind Oregon's bountiful resources: timber, recreational opportunities, agricultural products, 
water, wildlife, and minerals. Liddicoat \& Krasny (2014) report that students

participating in residential outdoor programs show gains in cognition, personal reflection, social interactions, and feelings of environmental stewardship. The goal is that these students will leave the ODS program with a deeper understanding of science and strong platform from which to develop into well-informed, confident citizens.

Outdoor School is often students' first extended stay away from home so an emphasis is placed on providing a safe, structured, and supportive learning environment. Students participate in a variety activities designed to encourage a team spirit, mutual respect, an inquisitive, optimistic approach to new experiences, and feelings of stewardship towards community and environmental concerns. Waite (2007) contends that relevance and positive emotions (enjoyment) lay the groundwork for future positive associations with learning. Question \#1 attempted to measure these theorized positive gains in student attitudes toward science. At each ODS site, ecosystems such as forests and streams become "study plots" for guided exploration and inquiry. The "Field Study" curriculum introduces students to the science of these natural systems and encourages students to apply their acquired knowledge in thoughtful ways. Participation in the Soil, Water, Animal, and Plant Field Studies provides an engaging, hands-on introduction to the form and function of organisms and ecosystems.

This project used observations of the Plant Field Study in the 3-day ODS program to answer questions $\# 2$ and $\# 3$. The researcher chose this field study because of the relevance an enhanced concept of plant biology/ecology has to an informed world view. An understanding of plants' role in energy flow and carbon cycling enables a more 
functional understanding of natural and man-made processes. Deforestation, unsustainable agricultural practices, and environmental damage caused by excessive consumption of fossil fuels are relevant concerns for humans on a worldwide scale. Deep understanding of the impact of these practices requires at least a basic grasp of the ecology and biology of plants. Creating and sustaining an educated citizenry is necessary for informed consideration and cooperation in regards to social and environmental policy. Unfortunately, students tend to show poor understanding of and interest in plants, underscoring the importance of including the science of plant ecology in outdoor education curricula (Fancovicova \& Prokop, 2010). The Plant Field Study provides the basis for a functional understanding of plant ecology and its relevance to humans. These outdoor lessons use a hands-on, in-situ approach that places emphasis on how plants' countless adaptations allow them to survive and reproduce in a wide array of environments. Students are encouraged to connect their observations and existing plant knowledge to processes and phenomena such as photosynthesis, competition, water and nutrient uptake, and predation. Specially trained ODS staff guides students through this process of discovery and connection.

Outdoor School assigns and trains staff in the instruction of specific Field Studies. At the beginning of each Field Study, these instructors introduce students to the key concepts and learning goals for their field experience. This is generally done outdoors, in close proximity to the system they will be studying. From the outset, students are encouraged to observe and think about what they are seeing. While the school district in this study cannot afford to send all their students to the six-day ODS program, the shorter 
three-day program is still considered be an invaluable addition to the students' overall educational experience. For the three-day program, each Field Study lasts an average of 2.5 hours. The 6-day programs is very similar to the 3-Day program during the morning Field Study introduction but, because the students stay with the same field study all day, has an additional afternoon session that goes into more depth on topics selected by the lead field instructor (photosynthesis, adaptations, etc.). Also, during the 6-day program students are also able to visit at least 2-3 educational "stations" as opposed to just one. Regardless of the length of the students' stay, a supportive, respectful learning environment that nurtures curiosity, inquiry and discussion is always the goal. After the introductory presentation, students are separated into smaller groups headed by volunteer student leaders from area high schools.

These student leaders are carefully chosen based on behavioral and academic merit and must be at least in their sophomore year. They function as instructional guides and counselors. In addition to being responsible for the general health and welfare of their "cabin group," they lead the students put in their care through interactive learning stations, group activities, and hikes tailored for learning in each Field Study. Trained to provide inquiry-based instruction, they are an essential interface between the students' they lead and the natural systems they are exploring as a team. Their purpose at ODS school is to use enthusiasm, subject knowledge, and inquiry to inspire curiosity and confidence towards science in the sixth grade campers. The student leaders work closely with ODS instructional staff and participate in formative assessment and professional development throughout their assignment, typically one week on site at ODS. 
The Outdoor School in this study strives to enable the district's students to learn science as well as interpersonal skills through innovative and collaborative leadership. The following table lists the mission goals stated by Outdoor School on their website (http://w3.mesd.k12.or.us/os/OutdoorSchool/Mission.html):

\title{
Table 4: Outdoor School Mission Goals
}

\begin{tabular}{|l|l|}
\hline 1 & $\begin{array}{l}\text { Teach field-based science concepts as they relate to natural resources. This instruction is hands- } \\
\text { on and meaningful for real life. }\end{array}$ \\
\hline 2 & Provide instruction that promotes critical thinking and collaboration. \\
\hline 3 & Extend science instruction beyond the classroom. \\
\hline 4 & $\begin{array}{l}\text { Implement a variety of planned activities that provide opportunities for participation in } \\
\text { cooperative living experiences, performing arts, recreation, and structured events. }\end{array}$ \\
\hline 5 & Provide for the safety, physical and medical needs of all students. \\
\hline 6 & Promote self-esteem, leadership and confidence in sixth grade and high school students. \\
\hline 7 & Practice gender/ethnic equity and honor and promote diversity and multicultural awareness. \\
\hline 8 & $\begin{array}{l}\text { Teach interpersonal skills and provide opportunities for the application of these skills across a } \\
\text { variety of settings. }\end{array}$ \\
\hline 9 & $\begin{array}{l}\text { Address the needs of all learners regardless of individual learning differences or challenged } \\
\text { conditions. }\end{array}$ \\
\hline 10 & \begin{tabular}{l} 
Treat each student and staff person with dignity and respect \\
\hline
\end{tabular} \\
\hline
\end{tabular}

\section{Instruments}

All instruments described in this section are available in their entirety in the appendix.

\author{
Affective Surveys. Students attending Outdoor School took"Student Affective Surveys" \\ measuring academic identity and motivational resilience as part "Bringing Assessment \\ Outdoors", a professional development and program improvement project developed and \\ implemented by the Multnomah Education Service District (MESD) and Outdoor School. \\ These surveys also measured sub-groups of academic identity (belonging/relatedness, \\ competence/efficacy, autonomy/ownership, and purpose) and motivational resilience
} (academic engagement and constructive coping). Students took these surveys shortly 
before and shortly after their participation in Outdoor School. Because the Outdoor School curriculum focuses on the science of natural systems, these surveys are a sciencespecific version of an instrument developed by the STEM Common Measurement System to evaluate MR and AI. These surveys were developed from two pre-existing instruments measuring MR and AI in order to balance the limitations of either in isolation (Saxton, et al., 2014). Efforts are currently underway to determine the validity of the combined instrument. Students use a five-point Likert-type scale to respond, or "self-report", how strongly they agree or disagree with statements designed to measure various components of academic identity and motivational resilience, as described below.

The STEM Common Measurement System identifies four components of academic identity to be measured: 1) sense of belonging or relatedness; 2) perceived competence or self-efficacy, which describes students' beliefs about whether they have the ability to succeed in STEM classes and fields; 3) autonomy or ownership, which refers to whether students are personally committed to the work in STEM classes and careers; 4) purpose, which relates to whether students are convinced that classwork and professional work in STEM is meaningful, important, and worthwhile (Saxton, et al., 2013). The Outdoor School project added a fifth AI sub-group to the instrument used in this study, identity, which measures how students see themselves succeeding in STEM and using it in their future careers. These components represent facets of students' selfconcept and their perceived ability to do well and find enjoyment in STEM classes and careers. The Portland Metro STEM Partnership considers AI to be a fundamental aspect of the effort and determination necessary for success in STEM fields. 
Examples of items measuring Academic Identity:

1. I am the kind of person who can succeed in Science.

2. People like me do not get jobs in Math/Science.

3. I feel at home in Science/Math.

Motivational resilience is defined by the STEM Common Measurement System as "students' enthusiastic hard work and persistence in the face of challenging STEM coursework"; the two components measured by the System are 1) academic engagement and 2) constructive coping/resilience" (Saxton, et al., 2013). Academic engagement includes hard work, follow-through, and enthusiasm towards subject matter; examples of coping/resilience are problem-solving, help-seeking, and persistence in the face challenges and setbacks (Saxton, et al., 2013).

Examples of items measuring Motivational Resilience:

1. Science scares me.

2. When I don't understand something in Science, I feel like it's all my fault.

3. If a problem or project in Science is really difficult, I just work harder.

Formative Assessment Probe. This study added a Page Keeley formative assessment probe (Keeley, Eberle, \& Tugel, 2007) to the pre-survey as a means of gauging students' knowledge of what defines a plant before attending Outdoor School. The probe question "Is it a Plant" is designed to pinpoint student knowledge and misconceptions regarding 
plants. Students are given a list of plants and non-plant organisms and asked to identify the plants and explain their reasoning. This project used the students' written explanations to evaluate their prior knowledge of plants. It is not known if this probe has been validated as a measure of students' conceptual knowledge, however, 'Keeley probes" are commonly used in education as a useful means for formative assessment.

Field Notes. This study's second and third research questions required careful observation of instructional content during the Plant Field Study. Detailed notes documented which topic were covered, relevant vocabulary that was incorporated into the curriculum, and consistency among instructors. Only introductory material delivered by lead field instructors in the Plants Field Study who gave written assent were observed. These observations took place at Sandy River, Arrah Wannah, and Howard Outdoor School sites during the Spring 2015 session.

\section{Procedures}

Data collection for this study took place during the Spring 2015 Outdoor School session. This session began March 30 ${ }^{\text {th }}$ and ended May 15 ${ }^{\text {th }}$.

\section{Question \#1:}

Pre-surveys were distributed to teachers in the David Douglas School District one month before the start of ODS. These surveys included instructions for teachers to administer them to students as close to the start of ODS as possible (no more than two weeks before). Postage paid return envelopes were included with the surveys. Postsurveys were distributed to these teachers on the day they departed with their classes 
from ODS. These surveys included instructions to be administered no more than two weeks after their students' ODS experience.

Once all pre and post surveys had been collected, the results were entered into Excel spreadsheets for organization and analysis. Pre-post affective survey scores measuring academic identity and motivational resistance, as well as their sub groups, were subjected to statistical analysis using a paired $t$ test as the data analysis tool. Three levels of analysis were performed:

1) Total survey scores (academic identity + motivational resilience);

2) Separate academic identity and motivational resilience scores;

3) Individual MR and AI sub group scores (relatedness, competence, autonomy, etc.)

\section{Question \#2:}

Detailed field notes of introductory instructional content in the Plants Field Study were taken once a week during the seven week Outdoor School session. These observations took place at all three ODS sites. To avoid introduction of bias the researcher had no prior knowledge of any demographic characteristics of the student groups being observed. The only selection criteria applied to the groups is that they had to be taking part in the Plant Field Study during the 3-day ODS program. The field notes were compared to Middle School Life Science Disciplinary Core Ideas and Practices. This data was organized into tables displaying instructional alignment with NGSS DCIs. 
The field notes were considered to "align" with the NGSS DCI's if they could be easily connected to specific concepts outlined by the DCIs. Almost all the content could be augmented/fine-tuned to relate to these DCI's but for the purpose of this project, "easy" was defined as being explicitly relatable and requiring minimal explanation to establish connection. For example, an overview of the ingredients of photosynthesis (carbon dioxide, water, and sunlight) during the introduction to Plants Field Study at the Sandy River ODS site are readily connected to LS1:C because this DCI states that: "Plants, algae (including phytoplankton), and many microorganisms use the energy from light to make sugars (food) from carbon dioxide from the atmosphere and water through the process of photosynthesis, which also releases oxygen. These sugars can be used immediately or stored for growth or later use."

NGSS Science Inquiry Practices \#1-5 were used to evaluate alignment of field instruction to Practices. These first five Practices, 1) asking questions; 2) developing and using models; 3) planning and carrying out investigations; 4) analyzing and interpreting data; and 5) using mathematical and computation thinking are those that students are most likely to encounter during their 3-day stay at ODS and are Practices that were observed to occur during the study. Practices 6-8 certainly have the potential to be incorporated into ODS curriculum but are assumed in this study to require more time to introduce and develop than is typically available during the 3-day program. 


\section{Question \#3:}

This question used data from both Plants Field Study introductory instructional material and a written response section from a Page Keeley formative assessment probe. Data from Plants Field Study instructional content was summarized into tables displaying how instruction aligned with NGSS MS-LS 1,2,3, and/or 4.

Prior plant knowledge was measured using a Keeley formative assessment probe (“What is a Plant?”). The probe gave a list of 14 organisms and students were asked identify which ones were plants. Students were then asked to describe the "rule" they used to determine which of these organisms could be classified as plants. Students' responses on the "Is it a Plant?" Keeley formative assessment probe were examined for vocabulary used to define plants. Scores were assigned based on how many student responses aligned with 18 emergent response themes. All instruments use an anonymous coding system to protect student confidentiality and avoid introduction of bias.

To measure students' prior plant knowledge alignment with NGSS MS-LS DCIs, the emergent themes from the Keeley formative assessment probe were compared to the NGSS DCI's to ascertain which student responses could be easily connected to the aforementioned NGSS standards. "Easily" in this context meant that the concepts were explicitly relatable and required minimal explanation to establish connection. For example, a student response of "photosynthesis" was "easily" relatable to MS-LS1 because DCI LS1.C states that: "Plants, algae (including phytoplankton), and many microorganisms use the energy from light to make sugars (food) from carbon dioxide from the atmosphere and water through the process of photosynthesis, which also 
releases oxygen. These sugars can be used immediately or stored for growth or later use."

Data from this process was organized in tables showing which student responses could be aligned NGSS MS-LS1,2,3, and/or 4.

The Next Generation Science Standards used for this project are outlined in Table 5. This table presents the "layers" of the NGSS Middle School Life Science Disciplinary Core Ideas. There are four main broad categories (e.g., MS-LS 1 - From molecules to organisms: Structures and processes), followed by their subcategories, which are followed by more detailed but still concise topic descriptions, and finally the specific Performance Expectations for each DCI, which are science inquiry (or engineering design) specific instructional supports for educators.

Table 5: NGSS Disciplinary Core Ideas: Middle School Life Science

\begin{tabular}{|c|c|}
\hline MS-LS 1 - From molecules to organisms: Structures and processes \\
\hline LS1.A: Structure and Function \\
\hline$\bullet$ & $\begin{array}{l}\text { All living things are made up of cells, which is the smallest unit that can be said to be } \\
\text { alive. An organism may consist of one single cell (unicellular) or many different numbers } \\
\text { and types of cells (multicellular). (MS-LS1-1) }\end{array}$ \\
\hline$\bullet$ & $\begin{array}{l}\text { Within cells, special structures are responsible for particular functions, and the cell } \\
\text { membrane forms the boundary that controls what enters and leaves the cell. (MS-LS1-2) }\end{array}$ \\
\hline$\bullet$ & $\begin{array}{l}\text { In multicellular organisms, the body is a system of multiple interacting subsystems. These } \\
\text { subsystems are groups of cells that work together to form tissues and organs that are } \\
\text { specialized for particular body functions. (MS-LS1-3) }\end{array}$ \\
\hline$\bullet$ & $\begin{array}{l}\text { Animals engage in characteristic behaviors that increase the odds of reproduction. (MS- } \\
\text { LS1-4) }\end{array}$ \\
\hline$\bullet$ & $\begin{array}{l}\text { Plants reproduce in a variety of ways, sometimes depending on animal behavior and } \\
\text { specialized features for reproduction. (MS-LS1-4) }\end{array}$ \\
\hline & Genetic factors as well as local conditions affect the growth of the adult plant. (MS-LS1-5) \\
\hline LS1.B: Growth and Development of Organisms & $\begin{array}{l}\text { Plants, algae (including phytoplankton), and many microorganisms use the energy from } \\
\text { light to make sugars (food) from carbon dioxide from the atmosphere and water through } \\
\text { the process of photosynthesis, which also releases oxygen. These sugars can be used } \\
\text { immediately or stored for growth or later use. (MS-LS1-6) }\end{array}$ \\
\hline $\begin{array}{l}\text { WS1.C: Organization for Matter and Energy Flow individual organisms, food moves through a series of chemical reactions in which } \\
\text { it is broken down and rearranged to form new molecules, to support growth, or to release } \\
\text { energy. (MS-LS1-7) }\end{array}$ \\
\hline LS1.D: Information Processing
\end{tabular}




\begin{tabular}{|c|c|}
\hline • & $\begin{array}{l}\text { Each sense receptor responds to different inputs (electromagnetic, mechanical, chemical), } \\
\text { transmitting them as signals that travel along nerve cells to the brain. The signals are then } \\
\text { processed in the brain, resulting in immediate behaviors or memories. (MS-LS1-8) }\end{array}$ \\
\hline \multicolumn{2}{|c|}{ MS-LS 2 - Ecosystems: Interactions, energy, and dynamics } \\
\hline \multicolumn{2}{|r|}{ LS2.A: Interdependent Relationships in Ecosystems } \\
\hline & $\begin{array}{l}\text { Organisms, and populations of organisms, are dependent on their environmental } \\
\text { interactions both with other living things and with nonliving factors. (MS-LS2-1) }\end{array}$ \\
\hline & $\begin{array}{l}\text { In any ecosystem, organisms and populations with similar requirements for food, water, } \\
\text { oxygen, or other resources may compete with each other for limited resources, access to } \\
\text { which consequently constrains their growth and reproduction. (MS-LS2-1) }\end{array}$ \\
\hline & $\begin{array}{l}\text { Growth of organisms and population increases are limited by access to resources. (MS- } \\
\text { LS2-1) }\end{array}$ \\
\hline & $\begin{array}{l}\text { Similarly, predatory interactions may reduce the number of organisms or eliminate whole } \\
\text { populations of organisms. Mutually beneficial interactions, in contrast, may become so } \\
\text { interdependent that each organism requires the other for survival. Although the species } \\
\text { involved in these competitive, predatory, and mutually beneficial interactions vary across } \\
\text { ecosystems, the patterns of interactions of organisms with their environments, both living } \\
\text { and nonliving, are shared. (MS-LS2-2) }\end{array}$ \\
\hline \multicolumn{2}{|c|}{ LS2.B: Cycle of Matter and Energy Transfer in Ecosystems } \\
\hline & $\begin{array}{l}\text { Food webs are models that demonstrate how matter and energy is transferred between } \\
\text { producers, consumers, and decomposers as the three groups interact within an ecosystem. } \\
\text { Transfers of matter into and out of the physical environment occur at every level. } \\
\text { Decomposers recycle nutrients from dead plant or animal matter back to the soil in } \\
\text { terrestrial environments or to the water in aquatic environments. The atoms that make up } \\
\text { the organisms in an ecosystem are cycled repeatedly between the living and nonliving } \\
\text { parts of the ecosystem. (MS-LS2-3) }\end{array}$ \\
\hline \multicolumn{2}{|r|}{ LS2.C: Ecosystem Dynamics, Functioning, and Resilience } \\
\hline & $\begin{array}{l}\text { Ecosystems are dynamic in nature; their characteristics can vary over time. Disruptions to } \\
\text { any physical or biological component of an ecosystem can lead to shifts in all its } \\
\text { populations. (MS-LS2-4) }\end{array}$ \\
\hline & $\begin{array}{l}\text { Biodiversity describes the variety of species found in Earth's terrestrial and oceanic } \\
\text { ecosystems. The completeness or integrity of an ecosystem's biodiversity is often used as a } \\
\text { measure of its health. (MS-LS2-5) }\end{array}$ \\
\hline \multicolumn{2}{|r|}{ LS4.D: Biodiversity and Humans } \\
\hline & $\begin{array}{l}\text { Changes in biodiversity can influence humans' resources, such as food, energy, and } \\
\text { medicines, as well as ecosystem services that humans rely on — for example, water } \\
\text { purification and recycling.(secondary to } M S-L S 2-5 \text { ) }\end{array}$ \\
\hline \multicolumn{2}{|c|}{ MS-LS 3 - Heredity: Inheritance and variation of traits } \\
\hline \multicolumn{2}{|c|}{ LS1.B: Growth and Development of Organisms } \\
\hline & $\begin{array}{l}\text { Organisms reproduce, either sexually or asexually, and transfer their genetic information to } \\
\text { their offspring. (secondary to MS-LS3-2) }\end{array}$ \\
\hline \multicolumn{2}{|r|}{ LS3.A: Inheritance of Traits } \\
\hline & $\begin{array}{l}\text { Genes are located in the chromosomes of cells, with each chromosome pair containing two } \\
\text { variants of each of many distinct genes. Each distinct gene chiefly controls the production } \\
\text { of specific proteins, which in turn affects the traits of the individual. Changes (mutations) }\end{array}$ \\
\hline
\end{tabular}




\begin{tabular}{|c|c|}
\hline & $\begin{array}{l}\text { to genes can result in changes to proteins, which can affect the structures and functions of } \\
\text { the organism and thereby change traits. (MS-LS3-1) }\end{array}$ \\
\hline & $\begin{array}{l}\text { Variations of inherited traits between parent and offspring arise from genetic differences } \\
\text { that result from the subset of chromosomes (and therefore genes) inherited. (MS-LS3-2) }\end{array}$ \\
\hline \\
\hline \multicolumn{2}{|c|}{$\begin{array}{l}\text { LS3.B: Variation of Traits } \\
\text { random) by the offspring. Individuals have two of each chromosome and hence two alleles } \\
\text { of each gene, one acquired from each parent. These versions may be identical or may } \\
\text { differ from each other. (MS-LS3-2) }\end{array}$} \\
\hline & $\begin{array}{l}\text { In addition to variations that arise from sexual reproduction, genetic information can be } \\
\text { altered because of mutations. Though rare, mutations may result in changes to the structure } \\
\text { and function of proteins. Some changes are beneficial, others harmful, and some neutral to } \\
\text { the organism. (MS-LS3-1) }\end{array}$ \\
\hline \multicolumn{2}{|c|}{ MS-LS 4 - Biological Evolution: Unity and Diversity } \\
\hline \multicolumn{2}{|c|}{ LS4.A: Evidence of Common Ancestry and Diversity } \\
\hline & $\begin{array}{l}\text { The collection of fossils and their placement in chronological order (e.g., through the } \\
\text { location of the sedimentary layers in which they are found or through radioactive dating) is } \\
\text { known as the fossil record. It documents the existence, diversity, extinction, and change of } \\
\text { many life forms throughout the history of life on Earth. (MS-LS4-1) }\end{array}$ \\
\hline & $\begin{array}{l}\text { Anatomical similarities and differences between various organisms living today and } \\
\text { between them and organisms in the fossil record, enable the reconstruction of evolutionary } \\
\text { history and the inference of lines of evolutionary descent. (MS-LS4-2) }\end{array}$ \\
\hline & $\begin{array}{l}\text { Comparison of the embryological development of different species also reveals similarities } \\
\text { that show relationships not evident in the fully-formed anatomy. (MS-LS4-3) }\end{array}$ \\
\hline \\
\hline \multicolumn{2}{|c|}{$\begin{array}{l}\text { LS4.B: Natural Selection } \\
\bullet \quad \text { Natural selection leads to the predominance of certain traits in a populati }\end{array}$} \\
\hline & $\begin{array}{l}\text { In artificial selection, humans have the capacity to influence certain characteristics of } \\
\text { organisms by selective breeding. One can choose desired parental traits determined by } \\
\text { genes, which are then passed on to offspring. (MS-LS4-5) }\end{array}$ \\
\hline \multicolumn{2}{|c|}{ LS4.C: Adaptation } \\
\hline & $\begin{array}{l}\text { Adaptation by natural selection acting over generations is one important process by which } \\
\text { species change over time in response to changes in environmental conditions. Traits that } \\
\text { support successful survival and reproduction in the new environment become more } \\
\text { common; those that do not become less common. Thus, the distribution of traits in a } \\
\text { population changes. (MS-LS4-6) }\end{array}$ \\
\hline
\end{tabular}

It should be noted that some DCIs contain subtopics that are borrowed from other

DCIs. For example, LS1.B is mentioned (in slightly different form) in both LS1: From

molecules to organisms: Structures, as well as LS3:Heredity: Inheritance and variation of

traits. Additionally, LS4.D: Biodiversity in humans is categorized under LS2: 
Ecosystems: Interactions, energy, and dynamics. This rearrangement is seen throughout grade bands as related concepts are cross referenced. The data tables in the Results section do not reflect this rearrangement - all DCIs are shown in numerical order.

The next section presents the quantitative and qualitative results of the questions proposed in this study: statistical analysis of the pre-post affective surveys ("Attitudes toward Science"); alignment of ODS Plants Field Study introductory instructional material with NGSS Middle School Life Science Disciplinary Core Ideas and Science Inquiry Practices; and a comparison of MS-LS DCI alignment of Plants Field Study introductory instructional material and students' previous knowledge data from the "Is it a Plant?" Page Keeley formative assessment probe. 


\section{Results}

This project approached the classroom - Outdoor School learning continuum from multiple angles: 1) its relationship to changes in student attitudes towards science following participation in ODS; 2) current alignment of the Plants Field Study introductory instructional content with NGSS MS-LS DCIs and Science Inquiry Practices; and 3) a comparison of NGSS DCI alignment between students' prior knowledge of plants and instructional content in the Plants Field Study.

Statistical analysis of the results measured by the instrument used in Question \#1 indicated an overall positive change in student attitudes towards science. Analysis of affective sub-groups revealed varying significance in student outcomes. Examination of the alignment of Plants Field Study instruction to NGSS DCIs and Practices showed that robust alignment is occurring in both domains, with no formal, dedicated attempt in place yet. Comparison of DCI alignment in Plants Field Study instruction with DCI alignment of previous knowledge of plants data indicates that students are bringing useful academic language to ODS - much of it in general alignment with Plants Field Study instruction.

Question \#1: How are student attitudes toward science affected by attending Outdoor School?

Pre-post affective survey scores measuring academic identity and motivational resistance, as well as their sub groups, were subjected to statistical analysis using a paired t test as the data analysis tool. 
Tables 6-8 display the statistical analysis of the data used to answer Question \#1. $\mathrm{P}$ values were not found to be significant for AI relatedness, AI autonomy; MR total, MR engagement, and MR constructive coping. Significant positive P values were found for the total affective scores (cumulative AI plus cumulative MR), AI total, Identity, Competence, Purpose. T-stat and P values indicate that the greatest positive changes were seen in STEM Identity, Competence, and Purpose.

Table 6: Total Affective Score

\begin{tabular}{|l|l|}
\hline $\mathrm{n}=115$ & Total Affective Score \\
\hline $\mathrm{t}$-stat & -4.27699 \\
\hline P value & $3.96 \mathrm{E}-05$ \\
\hline
\end{tabular}

Table 7: Paired t-test for Academic Identity and Sub-Groups

\begin{tabular}{|l|l|l|l|l|l|l|}
\hline $\mathrm{n}=115$ & \multicolumn{4}{|l|}{$\begin{array}{l}\text { Academic } \\
\text { Identity }\end{array}$} & \multicolumn{5}{|l|}{ AI Sub-Groups } \\
\cline { 2 - 7 } & Total & Identity & Relatedness & Competence & Autonomy & Purpose \\
\hline t-stat & -6.14826 & -6.14704 & -1.94945 & -3.88293 & -1.78489 & -3.2253 \\
\hline P value & $1.19 \mathrm{E}-08$ & $1.19 \mathrm{E}-08$ & 0.053697 & 0.000173 & 0.076939 & 0.001642 \\
\hline
\end{tabular}

Table 8: Paired t-test for Motivational Resilience and Sub-Groups

\begin{tabular}{|l|l|l|l|}
\hline $\mathrm{n}=115$ & $\begin{array}{l}\text { Motivational } \\
\text { Resilience }\end{array}$ & MR Sub-Groups \\
\cline { 2 - 4 } & Total & Engagement & $\begin{array}{l}\text { Constructive } \\
\text { Coping }\end{array}$ \\
\hline t-stat & -1.09869 & -0.4587 & -1.13464 \\
\hline P value & 0.274218 & 0.64732 & 0.258906 \\
\hline
\end{tabular}


Question \#2: To which NGSS Disciplinary Core Ideas and Practices does introductory instruction in the Plants Field Study align?

The following tables present a general idea of how many times ODS introductory instruction content in Plants FS can be linked to NGSS DCIs and Practices. Each ODS site used as a data-source in this study has a table displaying DCI alignment, as well as a table displaying Science Inquiry Practice alignment.

\section{Sandy River ODS Site}


Table 9 shows that alignment occurred most frequently for MS-LS $1 \& 2$. MS-LS 4 showed about half as many alignment "hits." No explicit alignment was found for MSLS 3. Descriptions of the specific DCI sub-categories represented in this table can be found in Table 5.

Table 9: Sandy River Site NGSS DCI Alignment

\begin{tabular}{|c|c|c|c|c|c|c|c|c|c|c|c|c|c|}
\hline DCIs & & & & & & & & & & & & & \\
\hline & $\stackrel{\square}{\square}$ & $\stackrel{\stackrel{\oplus}{\vec{n}}}{\underline{\underline{n}}}$ & $\frac{u}{\vec{\Omega}}$ & $\frac{\rho}{\vec{n}}$ & 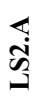 & 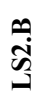 & 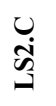 & 苛 & 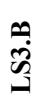 & $\begin{array}{l}\overleftrightarrow{+} \\
\stackrel{5}{3}\end{array}$ & 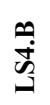 & 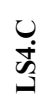 & 守 \\
\hline Instruction & & & & & & & & & & & & & \\
\hline Photosynthesis & $\mathrm{x}$ & $\mathrm{x}$ & $\mathrm{x}$ & & & $\mathrm{x}$ & & & & & & & \\
\hline Adaptation & $\mathrm{x}$ & $\mathrm{x}$ & $\mathrm{x}$ & & $\mathrm{x}$ & & & & & & & $\mathrm{x}$ & \\
\hline Stations & & & & & & & & & & & & & \\
\hline Clinometer Station & & & & & $\mathrm{x}$ & & $\mathrm{x}$ & & & & & & $\mathrm{x}$ \\
\hline Roots Station & $\mathrm{x}$ & & $\mathrm{x}$ & & & & & & & & & & \\
\hline Tree Parts & & $\mathrm{x}$ & & & $\mathrm{x}$ & $\mathrm{x}$ & & & & & $\mathrm{x}$ & $\mathrm{x}$ & \\
\hline Flower Parts & $\mathrm{x}$ & $\mathrm{x}$ & & & $\mathrm{x}$ & & & & & & $\mathrm{x}$ & $\mathrm{x}$ & $\mathrm{x}$ \\
\hline Fungi & $\mathrm{x}$ & $\mathrm{x}$ & & & $\mathrm{x}$ & $\mathrm{x}$ & & & & & & & \\
\hline Mosses \& Lichens & & & & & $\mathrm{x}$ & & $\mathrm{x}$ & & & & & & \\
\hline Total & 5 & 5 & 4 & & 7 & 4 & 2 & & & & 2 & 3 & 2 \\
\hline
\end{tabular}


Table 10 shows that the NGSS Science Inquiry Practices incorporated most frequently at the Sandy River ODS site were Practices \#1 (Asking Questions) and \#2 (Developing \& Using Models). Incorporation of Practice \#3 (Planning \& Carrying Out Investigations), \#4 (Analyzing and interpreting data), and \#5 (Using mathematics and computational thinking) occurred less frequently. The "Clinometer" exercise, an experiential learning activity in which students learned to calculate board feet in the context of timber harvest and construction, gave students the opportunity to implement 4 out of the 5 Science Inquiry Practices examined in this study.

Table 10: Sandy River Site NGSS Practices Alignment

\begin{tabular}{|l|l|l|l|l|l|}
\hline Practices & $\mathbf{1}$ & $\mathbf{2}$ & $\mathbf{3}$ & $\mathbf{4}$ & $\mathbf{5}$ \\
\hline Instruction & & & & & \\
\hline Photosynthesis & $\mathrm{x}$ & $\mathrm{x}$ & & & \\
\hline Adaptation & $\mathrm{x}$ & & $\mathrm{x}$ & & \\
\hline Habitat & & & & & \\
\hline Stations & & & & & \\
\hline Clinometer & $\mathrm{x}$ & & $\mathrm{x}$ & $\mathrm{x}$ & $\mathrm{x}$ \\
\hline Roots & $\mathrm{x}$ & & & & \\
\hline Tree Parts & $\mathrm{x}$ & $\mathrm{x}$ & & & \\
\hline Flower Parts & $\mathrm{x}$ & $\mathrm{x}$ & & & \\
\hline Fungi & $\mathrm{x}$ & $\mathrm{x}$ & & & \\
\hline Moss/Lichens & $\mathrm{x}$ & $\mathrm{x}$ & & & \\
\hline Total & 8 & 5 & 2 & 1 & 1 \\
\hline
\end{tabular}

\section{Camp Howard ODS Site}


Table 11 shows that alignment occurred most frequently in for MS-LS 1, followed by MS-LS 2 \& MS-LS 4 in descending frequency of "hits." No explicit alignment was found for MS-LS 3. Descriptions of the specific DCI sub-categories represented in this table can be found in Table 5 .

Table 11: Camp Howard Site NGSS DCI Alignment

\begin{tabular}{|c|c|c|c|c|c|c|c|c|c|c|c|c|c|}
\hline DCIs & $\frac{\square}{a}$ & 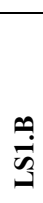 & $\frac{\text { ب̣ }}{\dot{\vec{s}}}$ & $\stackrel{\oplus}{\stackrel{9}{9}}$ & 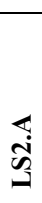 & 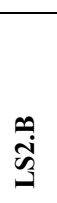 & $\begin{array}{l}0 \\
\tilde{N} \\
\end{array}$ & 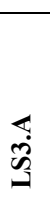 & 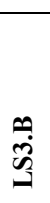 & 庭 & 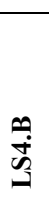 & 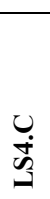 & 实 \\
\hline Instruction & & & & & & & & & & & & & \\
\hline Photosynthesis & $\mathrm{x}$ & $\mathrm{x}$ & $\mathrm{x}$ & & $\mathrm{x}$ & $\mathrm{x}$ & & & & & & & $\mathrm{x}$ \\
\hline Adaptation & $\mathrm{x}$ & $\mathrm{x}$ & $\mathrm{x}$ & & $\mathrm{x}$ & $\mathrm{x}$ & & & & & & $\mathrm{x}$ & \\
\hline Stations & & & & & & & & & & & & & \\
\hline Ethno-botany & $\mathrm{x}$ & & & & & & & & & & & & $\mathrm{x}$ \\
\hline Tree Guts & $\mathrm{x}$ & & & & & & & & & & & & \\
\hline Carnivorous Plants & $\mathrm{x}$ & & & & $\mathrm{x}$ & $\mathrm{x}$ & & & & & & $\mathrm{x}$ & \\
\hline Logging Tools & & & & & $\mathrm{x}$ & & & & & & & & $\mathrm{x}$ \\
\hline Micro-scope & $\mathrm{x}$ & & & & & & & & & & & & \\
\hline Total & 6 & 2 & 2 & & 4 & 3 & & & & & 0 & 2 & 3 \\
\hline
\end{tabular}


Table 12 shows that the NGSS Science Inquiry Practice incorporated most frequently at the Sandy River ODS site was Practice \#1 (Asking Questions). Practice \#2 (Developing \& Using Models) was observed to occur once, during the "Tree Guts" learning station. Alignment with Practices \#3 (Planning \& Carrying Out Investigations), \#4 (Analyzing and interpreting data), or \#5 (Using mathematics and computational thinking) was not observed at Camp Howard.

Table 12: Camp Howard Site NGSS Practices Alignment

\begin{tabular}{|l|l|l|l|l|l|}
\hline Practices & $\mathbf{1}$ & $\mathbf{2}$ & $\mathbf{3}$ & $\mathbf{4}$ & $\mathbf{5}$ \\
\hline Instruction & & & & & \\
\hline Photosynthesis & $\mathrm{x}$ & & & & \\
\hline Adaptation & $\mathrm{x}$ & & & & \\
\hline Stations & & & & & \\
\hline Ethnobotany & $\mathrm{x}$ & & & & \\
\hline Tree Guts & $\mathrm{x}$ & $\mathrm{x}$ & & & \\
\hline $\begin{array}{l}\text { Carnivorous } \\
\text { Plants }\end{array}$ & $\mathrm{x}$ & & & & \\
\hline Logging Tools & $\mathrm{x}$ & & & & \\
\hline Microscope & $\mathrm{x}$ & & & & \\
\hline Total & 6 & 1 & 0 & 0 & 0 \\
\hline
\end{tabular}




\section{Camp Arrah Wanna ODS Site}

Table 13 shows that alignment occurred most frequently in for MS-LS $1 \& 2$, followed by MS-LS 4. No explicit alignment was found for MS-LS 3. Descriptions of the specific DCI sub-categories represented in this table can be found in Table 5.

Table 13: Camp Arrah Wanna Site NGSS DCI Alignment

\begin{tabular}{|l|l|l|l|l|l|l|l|l|l|l|l|l|l|}
\hline DCIs & & & & & & & & & & & & & \\
\hline Instruction & & & & & & & & & & & & & \\
\hline Photosynthesis & $\mathrm{x}$ & $\mathrm{x}$ & $\mathrm{x}$ & & $\mathrm{x}$ & $\mathrm{x}$ & & & & & & & \\
\hline Habitat & & & & & $\mathrm{x}$ & & $\mathrm{x}$ & & & & & & $\mathrm{x}$ \\
\hline Diversity & & $\mathrm{x}$ & & & $\mathrm{x}$ & $\mathrm{x}$ & $\mathrm{x}$ & & & & $\mathrm{x}$ & $\mathrm{x}$ & $\mathrm{x}$ \\
\hline Adaptation & & $\mathrm{x}$ & & & $\mathrm{x}$ & $\mathrm{x}$ & & & & & & $\mathrm{x}$ & \\
\hline Stations & & & & & & & & & & & & & \\
\hline Flower Parts & $\mathrm{x}$ & $\mathrm{x}$ & & & $\mathrm{x}$ & & & & & & & $\mathrm{x}$ & \\
\hline Tree Guts & $\mathrm{x}$ & & $\mathrm{x}$ & & $\mathrm{x}$ & & & & & & & & $\mathrm{x}$ \\
\hline Forestry & & & & & & & $\mathrm{x}$ & & & & & & $\mathrm{x}$ \\
\hline Plot Surveys & & & & & $\mathrm{x}$ & & $\mathrm{x}$ & & & & & & \\
\hline Ethnobotany & & & & & $\mathrm{x}$ & & & & & & & & $\mathrm{x}$ \\
\hline Mushrooms & $\mathrm{x}$ & & & & & $\mathrm{x}$ & & & & & & & \\
\hline Total & 4 & 4 & 2 & & 8 & 4 & 4 & & & & 1 & 3 & 5 \\
\hline
\end{tabular}


Table 14 shows that the NGSS Science Inquiry Practice incorporated most frequently at the Camp Arrah Wanna ODS site was Practice \#1 (Asking Questions). Alignment with Practice \#2 (Developing \& Using Models) was observed to occur at almost half the frequency of Practice \#1. Minimal alignment with Practices \#3 (Planning \& Carrying Out Investigations), \#4 (Analyzing and interpreting data), or \#5 (Using mathematics and computational thinking) was observed at Camp Arrah Wanna. The Plot Survey field study, an activity in which students measure species diversity in designated plots, supplied the opportunity to use 4 out of 5 Science Inquiry Practices.

Table 14: Camp Arrah Wanna NGSS Practices Alignment

\begin{tabular}{|l|l|l|l|l|l|}
\hline Practices & $\mathbf{1}$ & $\mathbf{2}$ & $\mathbf{3}$ & $\mathbf{4}$ & $\mathbf{5}$ \\
\hline Instruction & & & & & \\
\hline Photosynthesis & $\mathrm{x}$ & $\mathrm{x}$ & & & \\
\hline Habitat & $\mathrm{x}$ & $\mathrm{x}$ & & & \\
\hline Diversity & $\mathrm{x}$ & & & & \\
\hline Adaptation & $\mathrm{x}$ & & & & \\
\hline Stations & & & & & \\
\hline Flower Parts & $\mathrm{x}$ & $\mathrm{x}$ & & & \\
\hline Tree Guts & $\mathrm{x}$ & & & & \\
\hline Forestry & $\mathrm{x}$ & $\mathrm{x}$ & & & \\
\hline Plot Surveys & $\mathrm{x}$ & & $\mathrm{x}$ & $\mathrm{x}$ & $\mathrm{x}$ \\
\hline Ethnobotany & $\mathrm{x}$ & & & & \\
\hline Mushrooms & $\mathrm{x}$ & & & & \\
\hline Total & 10 & 4 & 1 & 1 & 1 \\
\hline
\end{tabular}


Tables 15 and 16 summarize the data found in Tables 9-14.

The most robust alignment between ODS Plants Field Study content and NGSS

DCIs was found with MS-LS $1 \& 2$, followed by MS-LS 4. No alignment was found with MS-LS 3 at the time of this study.

Table 15: Summary of ODS Site NGSS DCI Alignment (with sub-categories)

\begin{tabular}{|c|c|c|c|c|c|c|c|c|c|c|c|c|c|}
\hline & $\frac{4}{3}$ & $\stackrel{n}{3}$ & 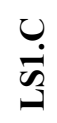 & $\stackrel{P}{\vec{n}}$ & 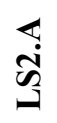 & 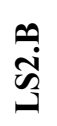 & 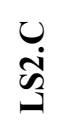 & $\underset{\infty}{\infty}$ & $\stackrel{\oplus}{\mathscr{m}}$ & 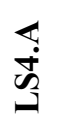 & 告 & 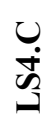 & 今 \\
\hline Sandy & 5 & 5 & 4 & & 7 & 4 & 2 & & & & 2 & 3 & 2 \\
\hline How. & 6 & 2 & 2 & & 4 & 3 & & & & & 0 & 2 & 3 \\
\hline $\mathbf{A W}$ & 4 & 4 & 2 & & 8 & 4 & 4 & & & & 1 & 3 & 5 \\
\hline Total & \multicolumn{4}{|l|}{34} & \multicolumn{3}{|l|}{36} & 0 & & \multicolumn{4}{|l|}{21} \\
\hline
\end{tabular}

ODS Plants Field Study aligned most robustly with Science Inquiry Practice \#1.

The next most frequent alignment was found to be with Practice \#2. Minimal alignment was found with Practices \#3, \#4, \& \#5.

Table 16: Summary of ODS NGSS Science Inquiry Practices Alignment

\begin{tabular}{|c|c|c|c|c|c|}
\hline & 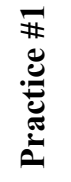 & 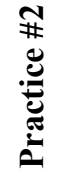 & 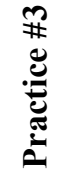 & 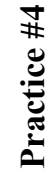 & 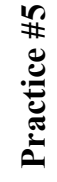 \\
\hline Sandy & 8 & 5 & 2 & 1 & 1 \\
\hline Howard & 6 & 1 & 0 & 0 & 0 \\
\hline AW & 10 & 4 & 1 & 1 & 1 \\
\hline Total & 24 & 10 & 3 & 2 & 2 \\
\hline
\end{tabular}


Question \#3: How does Plants Field Study NGSS DCI alignment compare to student prior knowledge NGSS DCI alignment?

\section{Student Prior Knowledge Alignment with NGSS MS-LS Disciplinary Core Ideas}

Table 17 displays general frequency of alignment between MS-LS2 DCIs and the students' prior knowledge of the definition of a plant. The most robust alignment was seen with MS-LS 1, while MS-LS 2 showed about half the amount of alignment as MSLS 1. No alignment was found for MS-LS $3 \& 4$. 
Table 17: Prior Knowledge as measured by the "Is it a Plant" Keeley Formative Assessment Probe

\begin{tabular}{|l|l|l|l|l|l|}
\hline$\#$ & Prior Knowledge Categories & MS-LS1 & MS-LS2 & MS-LS3 & MS-LS4 \\
\hline $\mathbf{1}$ & Grows on/in ground/needs soil & & $\mathrm{x}$ & & \\
\hline $\mathbf{2}$ & Is alive/grows & $\mathrm{x}$ & & & \\
\hline $\mathbf{3}$ & Comes from seed & $\mathrm{x}$ & & & \\
\hline $\mathbf{4}$ & Are edible/produce food & $\mathrm{x}$ & $\mathrm{x}$ & & \\
\hline $\mathbf{5}$ & Is/has flowers & $\mathrm{x}$ & & & \\
\hline $\mathbf{6}$ & Doesn't move & $\mathrm{x}$ & & & \\
\hline $\mathbf{7}$ & Has leaves & $\mathrm{x}$ & & & \\
\hline $\mathbf{8}$ & Needs sunlight & $\mathrm{x}$ & $\mathrm{x}$ & & \\
\hline $\mathbf{9}$ & Is green & $\mathrm{x}$ & $\mathrm{x}$ & & \\
\hline $\mathbf{1 0}$ & Has roots & $\mathrm{x}$ & $\mathrm{x}$ & & \\
\hline $\mathbf{1 1}$ & Makes own food & $\mathrm{x}$ & $\mathrm{x}$ & & \\
\hline $\mathbf{1 2}$ & "Photosynthesis" & $\mathrm{x}$ & $\mathrm{x}$ & & \\
\hline $\mathbf{1 3}$ & Attracts bees/animals & $\mathrm{x}$ & $\mathrm{x}$ & & \\
\hline $\mathbf{1 4}$ & Needs Water & Cell Wall/Plant Cells & $\mathrm{x}$ & & \\
\hline $\mathbf{1 5}$ & Needs Air & & & \\
\hline $\mathbf{1 6}$ & Comes from a plant & Hotal & & & \\
\hline $\mathbf{1 7}$ & Has a stem/branches & & & \\
\hline $\mathbf{1 8}$ & & & & \\
\hline
\end{tabular}




\section{Outdoor School Plants Field Study Alignment with NGSS MS-LS Disciplinary Core}

\section{Ideas}

Tables $18-20$ summarize individual ODS site alignment with NGSS MS-LS2 DCIs.

There are no sub-categories, as with Question \#2 DCI alignment data tables, so scores may differ in this section.

Table 18 shows that alignment with students' prior knowledge occurred most frequently for MS-LS1 \& 2. MS-LS4 showed about half as many alignment "hits" as 1 \& 2. No explicit alignment was found for MS-LS 3.

Table 18: Summary of Sandy River NGSS DCI Alignment

\begin{tabular}{|l|l|l|l|l|}
\hline DCIs * & MS-LS1 & MS-LS2 & MS-LS3 & MS-LS4 \\
\hline Instruction & & & & \\
\hline Photosynthesis & $\mathrm{x}$ & $\mathrm{x}$ & & \\
\hline Adaptation & $\mathrm{x}$ & $\mathrm{x}$ & & $\mathrm{x}$ \\
\hline Habitat & $\mathrm{x}$ & $\mathrm{x}$ & & \\
\hline Stations & & & & \\
\hline Clinometer Station & & $\mathrm{x}$ & & $\mathrm{x}$ \\
\hline Roots Station & $\mathrm{x}$ & & & \\
\hline Tree Parts & $\mathrm{x}$ & $\mathrm{x}$ & & $\mathrm{x}$ \\
\hline Flower Parts & $\mathrm{x}$ & $\mathrm{x}$ & & $\mathrm{x}$ \\
\hline Fungi & $\mathrm{x}$ & $\mathrm{x}$ & & \\
\hline Mosses \& Lichens & & $\mathrm{x}$ & & \\
\hline Total & 7 & 8 & 0 & 4 \\
\hline
\end{tabular}


Table 19 shows that alignment with student prior knowledge occurred similarly for MS-LS1, MS-LS2, \& MS-LS4. No alignment was found for MS-LS 3.

Table 19: Summary of Camp Howard NGSS DCI Alignment

\begin{tabular}{|l|l|l|l|l|}
\hline DCIs* & MS-LS1 & MS-LS2 & MS-LS3 & MS-LS4 \\
\hline Instruction & & & & \\
\hline Photosynthesis & $\mathrm{x}$ & $\mathrm{x}$ & & $\mathrm{x}$ \\
\hline Adaptation & $\mathrm{x}$ & $\mathrm{x}$ & & $\mathrm{x}$ \\
\hline Stations & & & & \\
\hline Ethnobotany & $\mathrm{x}$ & & & $\mathrm{x}$ \\
\hline Tree Guts & $\mathrm{x}$ & & & \\
\hline Carnivorous Plants & $\mathrm{x}$ & $\mathrm{x}$ & & $\mathrm{x}$ \\
\hline Logging Tools & & $\mathrm{x}$ & & $\mathrm{x}$ \\
\hline Microscope & $\mathrm{x}$ & & & \\
\hline Total & 6 & 4 & 0 & 5 \\
\hline
\end{tabular}


Table 20 shows the most robust ODS alignment to be with MS-LS2, followed by MS-LS1 \& 4 at half that level of alignment. No alignment was seen with MS-LS3.

Table 20: Summary of Camp Arrah Wannah NGSS DCI Alignment

\begin{tabular}{|l|l|l|l|l|}
\hline DCIs * & MS-LS1 & MS-LS2 & MS-LS3 & MS-LS4 \\
\hline Instruction & & & & \\
\hline Photosynthesis & $\mathrm{x}$ & $\mathrm{x}$ & & \\
\hline Habitat & & $\mathrm{x}$ & & $\mathrm{x}$ \\
\hline Diversity & $\mathrm{x}$ & $\mathrm{x}$ & & $\mathrm{x}$ \\
\hline Adaptation & $\mathrm{x}$ & $\mathrm{x}$ & & $\mathrm{X}$ \\
\hline Stations & & & & \\
\hline Flower Parts & $\mathrm{x}$ & $\mathrm{x}$ & & $\mathrm{X}$ \\
\hline Tree Guts & $\mathrm{x}$ & $\mathrm{x}$ & & \\
\hline Forestry & & & & \\
\hline Plot Surveys & & $\mathrm{x}$ & & \\
\hline Ethnobotany & & $\mathrm{x}$ & & \\
\hline Mushrooms & $\mathrm{x}$ & & & \\
\hline Totals: 3-Day & 4 & 8 & 0 & 4 \\
\hline
\end{tabular}


The following table summarizes the NGSS DCI alignment scores in Tables 18-20.

The cumulative scores show the most robust alignment of ODS Plants Field Study instruction to be with NGSS standards MS-LS1, MS-LS2, and MS-LS4. No explicit alignment was observed for MS-LS3.

Table 21: Summary of ODS NGSS DCI Alignment (no sub-categories)

\begin{tabular}{|l|l|l|l|l|}
\hline & MS-LS1 & MS-LS2 & MS-LS3 & MS-LS4 \\
\hline Sandy & 7 & 8 & 0 & 4 \\
\hline Howard & 6 & 4 & 0 & 5 \\
\hline AW & 4 & 8 & 0 & 4 \\
\hline Total & 17 & 20 & 0 & 13 \\
\hline
\end{tabular}




\section{Discussion}

Outdoor School's memorable nature is not surprising considering the abundance of research connecting positive emotional experiences with increased cognitive functioning. The "outdoors" supplies an authentic, often enjoyable environment for learning that can lead to deeper understanding of concepts and provide practical context for new ideas. This has exciting implications for linking indoor and outdoor education. The enjoyment and authenticity of outdoor learning offer an advantage at the outset for optimizing students' psychological and cognitive outcomes. In an era where classroom instructional theory is focusing on addressing students' psychological needs as a precursor for cognitive success, outdoor programs have the potential to connect to classroom learning and provide positive, authentic associations in which to root instructional content.

This project approached the classroom - Outdoor School learning continuum from multiple angles: 1) its relationship to changes in student attitudes towards science following participation in ODS; 2) current alignment of the Plants Field Study introductory instructional content with NGSS MS-LS DCIs and Science Inquiry Practices; and 3) a comparison of NGSS DCI alignment between students' prior knowledge of plants and instructional content in the Plants Field Study.

\section{Question 1: Student attitudes toward science}

Results of this study supported that overall student attitudes toward science improved as a result of their Outdoor School experience (Table 6). When examined by 
sub-component, however, the results told a more nuanced story of what was happening to student attitudes toward science at Outdoor School (Tables $7 \& 8$ ).

$\mathrm{P}$ values were not found to be significant for AI relatedness, AI autonomy; MR total, MR engagement, and MR constructive coping. Significant positive P values were found for the total affective scores (cumulative AI plus cumulative MR), AI total, Identity, Competence, Purpose. T-stat and $\mathrm{P}$ values indicate that the greatest positive changes were seen in STEM Identity, Competence, and Purpose, all sub-components of Academic Identity.

"STEM Identity", in this study, measured whether students can see themselves succeeding in STEM and using it in their future careers. Significant increases in STEM Identity could perhaps be attributed to the fact ODS may be the first time these students are exposed to scientific thinking and functioning in an environment away from the classroom, or at all. Fagerstam \& Blom (2013) found that students interviewed several months after an outdoor learning program would tell a story about themselves doing science, as opposed just talking about what their teacher did. These researchers attributed these cognitive gains to the multi-sensory nature, novelty, and positive emotions tied to outdoor learning. These kinds of authentic learning experiences may have the potential to radically alter students' view of themselves in relation to world beyond their homes and classrooms. In a study looking at the effects of career themed field trips designed around learning specific science concepts, Muscat \& Pace (2013) found that students came to appreciate out-of-classroom activities as viable ways to gather information. Additionally, the students came away with an enhanced appreciation for the relevance of careers and 
processes to which they had previously given little thought, how these facilities functioned, and that there was a strong human component. Seeing themselves in the role of a scientist and having scientific behavior modelled by ODS staff may be an extremely formative step in giving students the ability to see themselves in a role beyond what is immediately familiar or considered attainable to them.

Giving students the opportunity to see themselves and others in the role of scientists may increase their sense of self-efficacy, or competence, in science. This study indicated significant gains in feelings of competence in science and, like STEM Identity, may be attributable to the fact that students may be seeing themselves in the role of scientist for the first, or one of the first, times. Learning in such a stimulating environment such as the outdoors supplies an authentic, often enjoyable environment for learning that can lead to deeper understanding of concepts and provide practical context for new ideas. Increases in conceptual understanding can lead to improvements in attitudes towards plants and general biology content respectively, following outdoor educational programs (Fancovicova \& Prokop, 2011; Prokop, Tuncer, \& Kvasničák, 2007). Once students are able to visualize themselves as potentially competent in a career they had either previously given little thought or not considered possible, the doors of possibility are thrown open - they now stand upon a platform for growth in a direction they may have been previously unaware of. This kind of increased self-efficacy may allow students to make connections between their previous formative experiences, their newfound sense of competence in science, and broader aspirations and global concerns. 
When students connect their sense of competence in science to feelings of responsibility towards community, government, and global environmental concerns, a sense of purpose could be said to be emerging. Statistical analysis of the affective surveys indicated that "Purpose" was a third category that showed robust growth in students attending Outdoor School. This positive change could be closely tied to students' increases in feelings of STEM Identity and Competence as measured in this study. These results may be indicative of the integration of new concepts into pre-existing conceptual structures occurring in students attending ODS. The ODS curriculum emphasizes a science inquiry process that encourages asking questions and making inferences based on evidence. A shift from an emphasis on memorization and regurgitation of disjointed facts (and other practices which do not engage students on a sophisticated level) to a system where students critically examine, synthesize, and apply their knowledge provides opportunities for more meaningful learning (Muscat \& Pace, 2013). This “meaningful learning" may be imbuing students with the motivation to critically evaluate their world and make the changes they consider to be beneficial. It is especially encouraging that these positive changes to student attitudes are occurring in a group of students from a low-SES (socioeconomic) school district (as opposed to students with access to more resources and longer stays at ODS) and during a brief, 3-day stay at ODS. That such a short exposure to the ODS culture of learning significantly influences their feelings of STEM identity, competence, and purpose speaks loudly for Outdoor School's potential to positively impact student attitudes and learning. 
The lack of significant positive changes in the other subcomponents of this survey (AI relatedness, AI autonomy; MR total, MR engagement, and MR constructive coping) (Tables $7 \& 8$ ) may be due to the brief nature of the ODS learning experience, Changing psychological constructs such as autonomy, engagement, and constructive coping may require more intensive, repeated opportunities for students to interact with science curriculum material in addition to thoughtful classroom management strategies that develop students' self-confidence and coping-strategies.

\section{Question 2: Field instruction alignment to NGSS DCIs and Practices}

This section of the study evaluated alignment of the Plants Field Study introductory instructional content and learning stations with NGSS Middle School Life Science DCIs and Science Inquiry Practices. Field notes detailing instructional content were used to compare alignment and the resulting data was compiled into tables for comparison (Tables 9-16). Assigning DCIs to certain topics cultivated deep appreciation for the infinite connectivity of natural systems, from a micro- to a macro- scale. Additionally, an appreciation for the broad applicability of the DCIs came to the forefront. It was challenging to decide which DCIs were appropriate to assign to instruction and learning stations in the Plants Field Study because almost any concept in nature can eventually be connected to the LS DCIs. To keep things manageable, this study attempted to reference DCIs that kept it simple and were of a complexity appropriate for middle school aged students. For example, it was deemed more practical to use flowers as a way to illustrate natural selection and adaptation, as opposed to fungus, because middle school aged children, especially those with minimal exposure to 
"nature" may be more likely to be familiar with diversity in flower form than with differences in fungus forms. Another example would be associating carnivorous plants with DCI LS4.C: Adaptation. All species, of course, have adaptations but for this age group but the researcher felt carnivorous plants would be an intriguing of example of an unusual adaptation - the ability to digest insects to obtain nutrients. Such a surprising adaptation could be an effective way to get the students' attention and then explain that this trait gives the plants an advantage in a challenging environment. Carnivorous plants could also be used to elucidate the difference between a plant making its own food via photosynthesis and a plant obtaining the nutrients it needs for growth and certain metabolic process from insects, soil, etc.

The strongest overall DCI alignment, as judged by relative cumulative scores, was found in LS1: From molecules to organisms - Structures and Processes and LS2: Ecosystems - Interactions, energy, and dynamics (Table 15). LS1 is further divided into four subsections: Structure and Function; Growth and Development of Organisms; Organization for Matter and Energy Flow in Organisms; and Information Processing. LS2 is divided into: Interdependent Relationships in Ecosystems; Cycle of Matter and Energy Transfer in Ecosystem; and Biodiversity and Humans. These are topics which can be tied in a straightforward way to concepts such as photosynthesis and adaptation, as well as to content covered in learning stations, such as tree parts and flower parts.

A weaker connection, as judged by relative cumulative scores, was found to LS4 (Biological evolution: Unity and Diversity) and no explicit connection was found to LS3 (Heredity: Inheritance and variation of traits) (Table 15). A possible explanation is that 
these are both intricate concepts that require time and thoughtful instruction to develop understanding of and three days at camp just isn't doesn't provide enough time for such involved learning. While these concepts could certainly be introduced in a simple way or used to bolster previous knowledge that students are bringing with them to camp, time at Outdoor School may be best spent focused on concepts such Structure and Function, Ecology, and modeling scientific behavior and process. This complements the NGSS's goal to deepen scientific understanding in a few key areas, as opposed to the "mile wide and inch deep" approach. Genetics and Evolution are important subjects that can build off key science concepts acquired during middle school learning. Additionally, if middle school age students are able to participate in programs that focus on improving their attitudes toward science, they may be better able to visualize and identify with the benefits of persisting in difficult course work encountered in higher grades and in college.

If an educational program decides that focusing on building the behaviors associated with science confers the greatest advantages to participating students, the NGSS Science Inquiry Practices provide a sound framework to build around. This study examined alignment of the Plants Field Study introductory instruction and learning stations with the first five NGSS Science Inquiry Practices: 1) asking questions; 2) developing and using models; 3) planning and carrying out investigations; 4) analyzing and interpreting data; and 5) using mathematical and computation thinking (Tables 10, $12,14, \& 16)$.

Practices 1 and 2 were found to occur most frequently overall (Table 16). Practice 1, Asking Questions, was found to be applied almost universally throughout the Plants 
Field Study, presumably due to the emphasis on science inquiry at ODS. Students are constantly being encouraged to ask questions and are led on various scientific investigations by field instructors. For example, students in the Plants Field Study at the Sandy River Site are asked to form a hypothesis regarding which species of trees exhibit phototropism the most frequently. Then, while on their nature hike, students count how many trees (by species) they see exhibiting phototropism and use these numbers to either support or reject their original hypothesis. Practice 2, Developing and Using Models, was also encountered frequently - resulting from the common use of diagrams during the Plants Field Study instruction and learning stations. Practices 3, 4, and 5, while not incorporated as frequently, could also be connected to the activities such as the phototropism investigations at Sandy River, as well as a learning station exercise in which students learned to use a clinometer to calculate the board feet of lumber needed to add a hypothetical addition to the main lodge at the Sandy River Site. This learning station exercise involved several steps of calculations that included determining circumference, radius, the height of the tree, and how these numbers lead to the total number of board feet needed. These observations provide evidence that certain Practices are already soundly in place in some instances at ODS and could be incorporated to deepen understanding of concepts and provide students with the opportunity to act and feel like scientists. Outdoor School is an opportunity to take concepts that may be abstract or difficult to grasp in a classroom environment and apply them in a relevant way in a novel environment - an experience that has the power increase students' confidence in learning (O’Brien, 2009). 
The connection of previous knowledge with incoming knowledge is an integral part of understanding and retention. The next section of the study looked at how student prior knowledge and instruction in the Plants field study aligned with NGSS DCIs in comparison to each other. Leveraging students ODS learning off their previous knowledge allows educators in both settings a chance to increase the likelihood of retention and retention in recall in subject matter that spans the classroom/outdoor boundary. It is an opportunity to give inert knowledge vivid new life in a new setting, connecting to and reinforcing classroom experiences (Muscat \& Pace, 2013).

\section{Question 3: Previous knowledge, field instruction, and NGSS DCIs}

The ODS model of learning gives the students an opportunity to transfer previous learning to a context in which it can be applied in new, relevant ways. The knowledge capital, or prior knowledge, students bring with them to any learning situation provides a wealth of opportunity for anchoring new content. This prior knowledge can be tied to culture, community, science, sports, and myriad other situations the student may have experience with. Question \#3 attempted to make a baseline measure of the previous knowledge students bring with them to ODS in regards to what defines a plant. The vocabulary themes used to make this evaluation could be considered representative of the academic language sixth graders are bringing with them to the Plants Field Study. The more previous knowledge of plant-defining vocabulary students bring, the more opportunities they will have to make connections between ODS and previous knowledge - and misconceptions may also be addressed. 
Both previous knowledge and field instruction showed the most alignment with LS1: From Molecules to Organisms - Structures and Processes. One explanation for this result is that most of the responses on the Keeley Probe are either words/phrases that describe plant structures (leaves, flowers, seed, stem, branches, etc.) or words/phrases that describe the process photosynthesis (makes own food, needs sunlight, needs air, etc.), so are easily aligned with LS1 (Table 17). This coincidental alignment of both previous knowledge and ODS instructional practice could actually serve as a model of an ideal plan for a classroom-ODS continuum. Field trips, for example, provide opportunities to retrieve prior knowledge and apply it in new contexts (Nadelson \& Jordan, 2012). Any cooperation that could take place between classroom teachers and ODS instructors could lead to considerable cognitive gains for students. Outdoor School provides an opportunity to provide practical application for concepts learned in the classroom, cementing knowledge important for success in higher grade bands.

Multiple connections could be made to LS2 for both previous knowledge (Table 17) as well as ODS instruction (Tables 18-21). The previous knowledge vocab was primarily tied to the process of photosynthesis and interactions with other animals, important concepts for having conversations with students about the interdependent relationships among organisms in ecosystems, as well as discussing the cycle of matter and energy through these systems. Again, there is the opportunity for ODS to build on the basic academic language students are bringing with them. Developing a system for evaluating this previous knowledge would be a logical step towards optimizing student learning in the indoor/outdoor learning continuum. Both traditional and non-formal 
educators should not assume that topics studies in class are permanently stored in memory, but instead make every effort to give students repeated opportunities to apply their knowledge in an authentic context. Muscat \& Pace (2013) compared pre- and postvisit concept maps drawn by students who had gone on field trips to career oriented locations and found the post-visit maps added new concepts as well as new detail to existing concepts. Additionally, unnecessary statements were omitted and misconceptions were addressed and corrected. Their research showed that these out-of-the-classroom experiences helped students integrate prior knowledge that was not previously seen as relevant with new, authentic experiences. Building on prior knowledge is an essential ingredient of teaching, and learning outdoors is associated with increased levels of retention and recall, often attributed to the rich emotional experiences associated with these learning environments (Waite, 2007).

Knowing what knowledge students aren't bringing with them is also important and can help inform instruction to a great extent. For example, neither the Keeley Probe results (previous knowledge)(Table 17) nor Plants Field Study exhibited alignment with LS3: Heredity (Tables 18-21). This could be useful as either support for integrating this material into the curriculum or as evidence that it is not material that would be productive to add (since students are not doing any work with it in the classroom yet). Interestingly, data from this section shows that, while previous knowledge does not align with LS4, there is frequent alignment of LS4 with field instruction. This data could be used by ODS as evidence for more thoughtful integration of evolution into the classroom/ODS continuum or as evidence that, because of a lack of previous knowledge to build on, it 
would be best to focus instructional attention more towards LS1 and LS2 concepts. The prior student knowledge of plants illuminated by the Keeley Probe demonstrates that, with no formal attempt to cultivate prior knowledge to align with NGSS, students are coming to ODS rich in knowledge capital that can be used to anchor NGSS MS-LS concepts. Seventeen out of the eighteen different categories of student responses in the Keeley probe can be readily related to MS-LS1 DCIs and eight out of eighteen can be used to add relevance to MS-LS2 DCIs. While none of the student replies were explicitly tied to MS-LS3 \& 4, these gaps could be bridged as students' science understanding increased across grade bands. Five out of the six most frequently mentioned prior knowledge of plants categories (Grows on/in ground/needs soil; Is alive/grows; Comes from seed; Needs sunlight; Has roots; \& Needs Water) (Table 17) can be linked to MSLS1, suggesting that many ODS students already have the seeds of knowledge upon which can be built an ever-greater understanding of the structure and function of organisms and natural systems. Outdoor programs can supplement this prior biology knowledge by cultivating positive attitudes towards organisms in addition to this increased knowledge (Fancovicova \& Prokop, 2011). This prior knowledge has the potential to provide a platform of intellectual growth in many directions.

\section{Tying it all together:}

ODS can be very relevantly tied to classroom rooming learning, as both a way to provide an both an authentic scientific experience that utilizes prior knowledge, as well an experience that can be referenced after the fact. This kind of continuum between indoor \& outdoor learning (formal and non-formal) could be a case of the whole being 
greater than the sum of its parts but intentionality and organization are needed in program planning for success. While NGSS DCIs are content oriented, ODS can build on previous knowledge through hands-on activity as well as enhance instruction through incorporation of NGSS Science Inquiry Practices.

There are many strategies savvy teachers use to make baseline assessments of student knowledge to inform their instructional approaches. This study showed that students, with no intentional preparation, come to Outdoor School with a sturdy base of plant knowledge that can be easily tied to Next Generation Science Standards Disciplinary Core Ideas. This evaluation aimed to show that relatively little change would need to be made to the existing instructional approaches to optimize learning and proceed in a direction of thoughtful coordination between the indoor and outdoor learning experiences. For example, while connections to MS-LS3 (Heredity) and MS-LS4 (Evolution) were lacking, this could be remedied with minimal instructional adjustment on both the classroom and outdoor sides of the students' learning continuum. On the other hand, if there was consistently no alignment with certain DCIs, the case could be made that it would be most practical to focus on the DCIs already being hit upon and enhance connections between ODS and classroom learning using the existing alignment. An emphasis on integrating new learning experiences into a broader, organized framework that considers past experiences and goals for the future helps students to orient themselves in relation to the educational continuum and link their learning experiences coherently (Muscat \& Pace, 2013). Because Outdoor School already links so readily with NGSS DCIs and because NGSS has already been adopted in 14 states (with 
many more showing interest), these standards are a logical choice around which to establish a framework for linking science learning in the classroom with science-centered outdoor learning programs such as ODS.

Linking to NGSS provides an extra layer of relevance, while also serving as an organizing framework to combat the "mile wide and an inch deep", disconnected nature in which science often presented and transmitted to students. Complementary to the Disciplinary Core Ideas and Practices, Cross cutting concepts can be used to connect the different field studies and deepen students' appreciation for the connectivity between seemingly disparate fields of science. ODS occurs at the transition between NGSS grade bands. An indoor/outdoor continuum could use both grade bands as reference points and emphasize that adhering to NGSS can promote optimal learning in ODS, which sets kids up for success in higher grade bands. An ideal outcome would be that ODS was considered a free but highly advantageous and esteemed resource - closely tied to NGSS, as well as promoting natural resource education/careers.

Integrating NGSS need not be a cumbersome, intimidating affair. On the classroom side, teachers could be given list of "concept seeds" to work into their curriculum that align with ODS/NGSS goals. As shown by this study, field instruction already aligns to a significant extent and could be integrated into existing training programs or staff. NGSS could serve as unifying guide for instruction that still allows the instructors to be creative and unique in their approach. This approach might actually make instruction easier because of clearer expectations for instructors and students alike. Initial efforts to integrate NGSS would not even necessitate increasing similarity between 
the different sites' Field Study approach, but could focus instead on illuminating how close they were already coming to aligning with NGSS and formulating a plan to touch upon more DCIs in their instruction. Once staff has a better feel for what the NGSS encompasses and finds most important, unifying their approach to teaching could be implemented in a gradual way. 


\section{Conclusion}

The over-arching theme for this study was that student outcomes at ODS could be optimized by cultivating a continuum between classroom science learning and the ODS experience, built around the NGSS Disciplinary Core Ideas and Science Inquiry Practices framework. The first step that was essential to this process was understanding how Outdoor School fits into the psychological development of student, particularly in regards to science. This first part of this study helped to elucidate the dynamic changes occurring in students' view of themselves as scientists and how science fits into their world view. The most significant positive changes were found in students' "STEM Identity", "Competency", and "Purpose." Next, alignment of introductory instruction and learning centers in the Plants Field Study was examined for alignment with NGSS DCIs and Science Inquiry Practices. This step provided an opportunity to examine how close instruction in the Plants Field Study was already coming to aligning with NGSS DCIs and Practices. This kind of evaluation is an important step in developing a classroom/outdoor education continuum. The last part of this study compared NGSS DCI alignment of both Plants Field Study instruction and student prior knowledge of plants. Students were found to be bringing academic vocabulary with them to ODS that has the potential to inform and optimize Outdoor School curriculum and contribute to the formation of a learning continuum. Outdoor School staff and classroom teachers are poised to maximize their impact by integrating NGSS and that implementing such an approach would require a very reasonable amount of effort on their part. Many DCIs and 
Practices are already being used and field study content could be easily (and minimally) expanded to include DCI's that aren't currently being addressed. 


\section{Suggestions for Improvements and Future Research}

The research design for this study and future related studies could be improved upon in several ways. First of all, a control group that takes pre/post surveys would increase validity and insure adequate experimental control. Taking time to assemble both a control group composed of students who haven't attended Outdoor School and an experimental group composed of students who have recently attended Outdoor School could offer enhanced opportunity for comparison of results for all the questions presented in this study. For example, changes in the sub-components of academic identity and motivational resilience (Question \#1) may show significant differences between control and experimental groups. The creation of these groups would not be beyond the scope of current time and resource limits, as there are two ODS sessions (Fall \& Spring) - for a study conducted during the Fall session, the control group could be composed of students not attending ODS until the following Spring.

A second improvement to this study would expand the scope of the observations made of ODS instruction. The students in this study split into several different field study groups led by various student leaders and this could account for differences in student outcomes seen in this study (Question \#1). Different student leaders but consistent subject content can still lead to varying conversations and observations occurring in the field. A future research project detailing the instruction of both field instructors and student leaders could be very informative and be useful for unifying instruction while still encouraging the unique approaches of ODS educators. In addition to improvements on the current model, there are possibilities for extending this area of research. 
Any research shedding light on the changes in student learning outcomes resulting from Outdoor School attendance, and how these changes come about has the potential be valuable in the process of creating research informed learning continuums. For example, a case study surveying classrooms teachers that use Outdoor School as a reference for classroom concepts could provide rich data as to when and how this referencing takes place - is this referencing used primarily in anticipation of their ODS experience or is a reflective approach used? Does the anticipation and excitement before ODS enhance learning in the classroom? Does revisiting the material encountered at ODS lead to changes in retention and recall? Another possible research project with the potential to inform the creation of an indoor-outdoor learning continuum could compare instruction of the same content in both traditional classroom and outdoor learning settings. Data from such a project could be helpful in a scenario where ODS content was being designed to complement specific classroom lessons.

Many aspects of learning surrounding indoor/outdoor education are waiting be explored and used to inform education in a variety of settings, including those specializing in reaching students with learning disabilities, language differences, and other obstacles to traditional learning. In any classroom, mainstream, non-formal, or specialized, designing lessons and assessments around research-supported frameworks such as the Next Generation Science Standards can connect student learning across subjects and grades and inform the creation of pedagogical approaches specific to an indoor-outdoor learning continuum. 


\section{References}

A Framework for K-12 Science Education: Practices, Crosscutting Concepts, and Core Ideas. (2013). Retrieved from http://www.nap.edu/catalog/13165/a-framework-for-k-12science-education-practices-crosscutting-concepts

Bentsen, P., \& Jensen, F. S. (2012). The nature of "Udeskole": Outdoor learning theory and practice in Danish schools. Journal of Adventure Education and Outdoor Learning, v12 n3 p199-219. DOI: 10.1080/14729679.2012.699806

Cayton, P., and Frissell , V. (2009) "Becoming wildlife investigators: exploring bird habitats provides an avenue for fourth graders to develop process skills and connect with their community." Science and Children Sept. 2009: 30. Educators Reference Complete. Web. 26 Oct. 2014.

Fagerstam, E., \& Blom, J. (2013). Learning biology and mathematics outdoors: Effects and attitudes in a Swedish high school context. Journal of Adventure Education and Outdoor Learning, v13 n1 p56-75. DOI: 10.1080/14729679.2011.647432

Fancovicova, J., \& Prokop, P. (2011). Plants have a chance: Outdoor educational programmes alter students' knowledge and attitudes towards plants. Environmental Education Research, 17(4), 537-551. DOI:10.1080/13504622.2010.545874

Keeley, P., Eberle, F., \& Tugel, J. (2007). Chapter 12: Is It a Plant? Uncovering Student Ideas in Science, Volume 2: 25 More Formative; 2007, p91. Danvers, MA. NSTA Press.

Liddicoat, K.R., \& Krasny, M.R. (2014), Memories as useful outcomes of residential outdoor environmental education. The Journal of Environmental Education. 45:3, 178193, DOI: $10.1080 / 00958964.2014 .905431$

Muscat, M., \& Pace, P. (2013). The impact of site-visits on the development of biological cognitive knowledge. Journal of Baltic Science Education, 12(3), 337-351

Nadelson, L. S., \& Jordan, J. R. (2012). Student attitudes toward and recall of Outside Day: An environmental science field trip. Journal of Educational Research, 105(3), 220231.

O'Brien, L. (2009) Learning outdoors: The Forest School approach. Education 3-13: International Journal of Primary, Elementary and Early Years Education, 37: 1, 45-60. DOI: 10.1080/03004270802291798

Prokop, P., Tuncer, G., \& Kvasničák, R. (2007). Short-term effects of field programme on students' knowledge and attitude toward biology: A Slovak experience. Journal of Science Education \& Technology, 16(3), 247-255. DOI: 10.1007/s10956-007-9044-8

Saxton, E., Burns, R., Holveck, S., Kelley, S., Prince, D., Rigelman, N., \& Skinner, E.A. (2013). A common measurement system for K-12 STEM education: Adopting an education evaluation methodology that elevates theoretical foundations and systems 
thinking. Studies in Educational Evaluation v40, 18-35

doi:10.1016/j.stueduc.2013.11.005

Shin, W.S., Shin, C.S., Yeoun, P.S., \& Kim, J.J. (2011). The influence of interaction with forest on cognitive function. Scandinavian Journal of Forest Research, 26:6, 595598. DOI: $10.1080 / 02827581.2011 .585996$

Waite, S. (2007) 'Memories are made of this': Some reflections on outdoor learning and recall. Education 3-13: International Journal of Primary, Elementary and Early Years Education, 35:4, 333-347. DOI: 10.1080/03004270701602459

Zink, R., \& Burrows, L. (2008) 'Is what you see what you get?' the production of knowledge in-between the indoors and the outdoors in outdoor education. Physical Education and Sport Pedagogy, 13:3, 251-265. DOI: 10.1080/17408980701345733 


\title{
Appendix A: Keeley Formative Assessment Probe:
}

\author{
Copyright $\odot 2007$ NSTA. All rights reserved. For more information, go to www.nsta.org/permissions.
}

Life Science Assessment Probes

\section{Is It a Plant?}

Each of the things listed below can be found living and growing in its environment. Put an $\mathrm{X}$ next to the things that you consider to be plants.

\section{_fern _. grass}

_. vine $\quad$ grasshopper

mold

flower

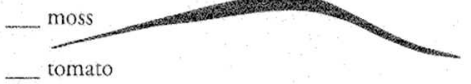

- onion

_.weed

n._tree

_ cactus

_bacteria

bush

_ cabbage

dandelion

_. mushroom

Explain your thinking. Describe the "rule" or reasoning you used to decide if something is a plant. 


\section{Appendix B: Outdoor School: Science Survey (pre-post)}

What is your Science Teacher's Last Name:

What school do you go to?

Date:

Please answer the questions below to create your own unique ID code for this and future surveys:
A. What are the last 2 letters of your last name? (If Smith, put ' $\mathrm{TH}$ ')
B. What is your day of birth. (If May $6^{\text {th }}$, you would put ' $06^{\prime}$ )
C. What is your middle name initial? (If John, enter J. If none, enter X)
D. How many older brothers do you have? (If none, enter 0 )
E. How many older sisters do you have? (If none, enter 0 )

We really want to know what you think of Science. Thank you for sharing your thoughts with us!

Please circle only one answer choice for each question.

1. I am the kind of person who can succeed in Science.
Not at all true A little bit true Somewhat true
Fairly true
Totally true

2. I want to be a scientist when I grow up.
Not at all true
A little bit true Somewhat true
Fairly true
Totally true

3. I want a job that uses Science when I grow up.
Not at all true
A little bit true Somewhat true
Fairly true
Totally true

4. People like me do not get jobs in Science.

Not at all true A little bit true Somewhat true

Fairly true

Totally true 


\section{Science doesn't have anything to do with me.}

Not at all true A little bit true Somewhat true Fairly true Totally true

\section{I feel at home in Science.}

Not at all true

A little bit true

Somewhat true

Fairly true Totally true

\section{Sometimes I feel like I don't belong in Science.}

Not at all true

A little bit true

Somewhat true

Fairly true

Totally true

\section{I am good at Science.}

Not at all true

A little bit true

Somewhat true

Fairly true

Totally true

9. I don't have the brains to do well in Science.

Not at all true

A little bit true

Somewhat true

Fairly true

Totally true

10. Why do I do my work in Science? Because it is personally important to me.

Not at all true

A little bit true

Somewhat true

Fairly true

Totally true

11. Why do I do my work in Science? Because they make us do it.

Not at all true

A little bit true

Somewhat true

Fairly true

Totally true

12. I believe that Science can help make the world a better place. 
13. Science is important for my future career.

Not at all true

A little bit true

Somewhat true

Fairly true

Totally true

14. I don't see the point of anything we are learning in Science.

Not at all true A little bit true Somewhat true Fairly true Totally true

15. There's no reason to learn Science.

$\begin{array}{llll}\text { Not at all true } \quad \text { A little bit true } \quad \text { Somewhat true } & \begin{array}{l}\text { Fairly } \\ \text { true }\end{array} \text { Totally true }\end{array}$

16. I try hard to do well in Science.

Not at all true

A little bit true

Somewhat true

Fairly

true Totally true

17. When we work on something in Science, it's pretty interesting.

Not at all true

A little bit true Somewhat true

Fairly

true

Totally true

18. I enjoy learning new things in Science.

Not at all true

A little bit true

Somewhat true

Fairly

true

Totally true

19. I don't really care about doing well in Science.

Not at all true

\begin{abstract}
A little bit true
\end{abstract}
Somewhat true
Fairly

true Totally true 
20. I can't stand working on Science.

$\begin{array}{llll}\text { Not at all true } \quad \text { A little bit true } \quad \text { Somewhat true } & \begin{array}{l}\text { Fairly } \\ \text { true }\end{array} \text { Totally true }\end{array}$

21. Science scares me.

$\begin{array}{llll} & \text { F little bit true } & \text { Soirly } & \\ \text { Not all true } & \text { Somhat true } & \text { Totally true }\end{array}$

22. If a problem or project in Science is really difficult, I just work harder.

Not at all true A little bit true Somewhat true Fairly true Totally true

23. If I don't do well on a Science problem or project, I figure out how to do better next time.
Not at all true
A little bit true
Somewhat true
Fairly true Totally true

24. If I don't understand something in Science, I ask for help.

Not at all true A little bit true Somewhat true Fairly true Totally true

25. When I have difficulty learning something in Science, I don't let it get me down.

Not at all true A little bit true Somewhat true Fairly true Totally true

26. When a problem or project in Science is hard, I just don't do it.

Not at all true A little bit true Somewhat true Fairly true Totally true

27. When I run into a hard problem or project in Science, I get all confused. 
Not at all true A little bit true Somewhat true Fairly true Totally true

28. If a problem or project in Science is really hard, I'll probably get it wrong.

Not at all true A little bit true Somewhat true Fairly true Totally true

29. When I don't understand something in Science, I feel like it's all my fault.

Not at all true A little bit true Somewhat true Fairly True Totally True 


\section{Appendix C: Field Notes}

\section{Outdoor School Notes}

\section{4-2-15}

General topics/ concepts (morning field study Daisy)

Photosynthesis

-asks kids what they know - one knew it is used to make FOOD from the sun.

-asks about other ingredients

-explains that most plants bring in WATER through roots

-explains need for and means of taking in $\underline{\mathrm{CO} 2}$ (through holes on leaves)

-produce 02

-plants use chlorophyll (a student knew this), this is what makes plants green - needed to capture sunlight.

-leaves fall to ground when they're out of chlorophyll

Plants need $\underline{\text { NUTRIENTS }}$ - get into soil via decomposition

-brief explanation of glucose (food)

$\underline{\text { Adaptation }}=\mathrm{a}$ feature of an organism that provides improved function within that population

-features that allow success (giraffe example - tongue, splayed hooves enable defense)

Plant Adaptations:

-poison: rash, photoxicity (cow’s parsnip)

-flowers

-color $=$ entices things to eat it

-Phototropism (emphasized)

-sun is source of energy, competition means plants must physically alter growth to get sunlight.

-has students look around to find tree exhibiting phototropism (lots of raised hands!)

-uses Western Red cedars in vicinity of shelter as examples (also Black Cottonwood and young Big Leaf Maples) leaning to get sunlight

-discusses meaning of hypothesis (explains that it is an educated guess) 
-explains to students what qualities make good learners (eye contact/tracking, listening, etc.)

(Most of this instructors intros are consistent with content information. Maybe I should to a collective summary instead of typing out each very similar lesson.)

\section{4-7-15 (Daisy)}

Intro:

What is chlorophyll? - made up of chloroplasts

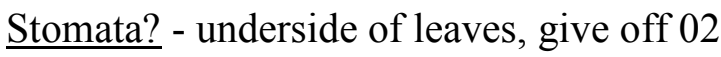

Plants are producers - can make food, we can't make our own food.

Introduces "adaptation" - uses giraffe as example, students are asked to give example of how giraffe's are adapted to environment.

Field Lesson: (see green worksheet for more details)

-hands out tools (tape measurer, calculator, compass)

-sets expectations: don't pick things or throw things, passing on trail etiquette (quiet), stay on trail.

Introduces "Clinometer" - hypothetical situation: addition to dining hall needs 2000 board feet of lumber (explains that a board foot is 144 cubic inches: 12 X 12 X 1), wood will come from trees

Math to determine board feet in a tree: circumference of tree/ $\mathrm{pi}=$ diameter of tree -students measure circumference of cedar in yard $=63$ inches

-brings out clinometer

-students take turns trying out clinometer

-use green worksheet to take average of students' observations from clinometer (tree height)

-once they figure out how many trees they need, FI has students identify nearby similar sized trees.

-allows those harvesting to not take too much.

Students open green field books (before Plants Hike):

-FI asks: Which tree species demonstrate phototropism the most? 
-students asked to describe their hypothesis (what will happen and why)

-choose between black cottonwood, WRCedar, or Big Leaf Maple.

-has students explain their answers and asks why. Uses inquiry process with students.

-has students put 3 bulleted points in design box:

-look for phototropic trees

-identify the tree

-count them

FI tells student root words of clinometer/ recaps measurement techniques with students.

"Roots" activity - demonstrated to student leaders by Daisy

-roots bring in $\mathrm{H} 20$ and nutrients.

-anchor for plant/stabilize

-prevents erosion

-root systems - complex plants vs. less-complex plants

Shows example:

-WR Cedar - askes students to describe what they see:

-tap-root system $=$ one big (primary) root that goes straight down

-also has smaller roots going to side (secondary roots - provide later support)

-tertiary roots come off secondary roots $=$ transport water and nutrients needed for photosynthesis.

-root hairs actually grab water and nutrients (microscopic)

Grass $=$ root mass, no tap root (secondary and tertiary only $)+$ root hairs $=$ "diffuse root system"

Teaches student leaders the "Root Song!"

Wrap-up meeting:

-Daisy asks questions:

-“Is WR Cedar Oregon state tree?" - no, Doug Fir

-Is a snag a dead, fallen tree" - no it's a dead, standing tree (great habitat)

-a nurse $\log$ is a dead, fallen tree. 
-Is phototropism an adaptation? - yes

-asks for other examples- students respond with:

-spiny leaves, thorns, winged-seeds, toxins, attractive or revolting smell (answers can vary from group to group but gives opportunity to give feedback/formative assessment)

Differences between 3 and 6 day programs:

Daisy -

6 day program:

-hike is $1 / 2$ hour longer

-2-3 stations (random access) as opposed to just one

Scott/Weasel-

6 day program:

- have time to visit all stations

-tree parts, flower parts, fungi, clinometer, roots, mosses and lichens

-same FS split between morning and afternoon

3 day program:

-2 FS per day (morning and afternoon)

-probably only get to one station

-some students may get to flower parts, trees, etc., - others may not

-Inquiry style learning could also account for differences in student learning experiences. Different student leaders but consistent subject content can still lead to varying conversations/ observations happening in the field.

\section{Stations:}

Moss and Lichens: fungus and algae

-algae: chlorophyll

-fungus: can see white, string-like fungus when FI scraps off algae. Fungus provides structure.

-lists different kinds of lichens (fruticose, crustose, etc.), shows example of crustose on WR Cedar. 
For 3-day program: Student leaders focus on certain "stations" during training, so this determines what the students in their care end up doing.

\section{4-14}

Daisy's wrap up:

-has students work in teams (groups they've been in all day) to answer questions: yes or no

-Doug Fir is state tree

-Snag is dead, standing tree

-Nurse log is fallen tree

-deciduous loses leaves in fall, gets new set in spring (examples)

-use inference to name another tree/s from their lives

-yews use "arrils" instead of cones. Males and females on different trees.

-garlic mustard $=$ invasive species

\section{Howard}

\section{5-7: Brain (email: ahickey1993@gmail.com)}

Structure and Function - parts and what they do.

Define basics

-science/scientist

$->$ Botany $=$ Plants

-tests things, specializes

-everyday-scientific method, an innate quality we use every day to stay warm, etc.

-practical hypothesis occur daily -> unconsciously calculating

We're ALL scientists! - we can be wrong and it okay

Isaac Newton - gravity

-asks himself questions about his observations

-right about gravity, wrong about alchemy

-wrong answers push us to be better scientists. 
Do plants have brains? - has students discuss/argue among themselves, urges them to give both sides thought. Yes! Or Nope!

Photosynthesis

-chloroplants

-absorb oxygen

-creates glucose

-no human life without photosynthesis

\section{Stations}

1) Ethnobotany

-relates to ethnicity

-culture's use of plants: food, decoration, building

2) Tree Guts

-layers of trees/functions

-cambium, xylem, phloem, outer bark, heartwood

3) Carnivorous Plants

-boggy areas

4) Logging Tools

5) Microscope

\section{5-7}

"Brain" afternoon intro:

Discussion with students:

Plants: cell wall, makes own food

Animals: no cell wall, hunts for food

Scientists on east coast have discovered a slug that has gained the ability to photosynthesize! - weird!, combines plant and animal DNA.

Asks them to be critical on hike, to challenge themselves and student leaders. 


\section{5-12 - Howard "Brain"}

Plants Intro:

What is science!

-asks kids for their thoughts

-experimenting, try things, learning new things

Brain: scientist is someone who is okay with getting answers that aren't expected.

Scientists are always wrong sometimes.

-make observations and comes to some kind of conclusion

-science is a way of solving problems

-everyone is a scientist!

Sir Isaac Newton

-right about gravity, wrong about alchemy - still made great contributions

Fungus is not a plant

Scientist think critically - rights and wrongs about things.

Do plants have brains? - discussed as a group conversation led by Brain

Adapted $=$ carnivorous plants adapted alternate ways of obtaining nutrients. Students will get to see partially digested insects at carnivorous plant station.

Photosynthesis: plants adapted to taking in $\mathrm{CO} 2$, pumping out $\mathrm{O} 2$

-plants produce glucose, a type of sugar, the simplest - only one the human brain can process!

-no glucose, no life!

The sun supports our lives.

Plants move to get light $=$ "Phototropism"

Review of P.E.R.C.H.

$\mathrm{P}=$ participation

$\mathrm{E}=$ environmental manners

$\mathrm{R}=$ respect

$\mathrm{C}=$ cooperation

$\mathrm{H}=$ have fun 


\section{5-19 = Arrawanna (Ginkgo)}

CO2 Dioxide

Chlorophyll

-in plants, look green

-no chlorophyll in roots or bark

-Leaves? - Yes!

Photosynthesis

1. Oxygen produced - we'd probably be dead without plants

2. Sugar called "Glucose" - making own food

Photo - means light in Latin

Synthesis - to produce/make

Light comes from sun.

Habitat - where a living thing calls home/ a place where things might live -forest, city, desert

Arrawanna - has forest (old and new), meadow, edge (where two habitats come together) -which has most diversity? - when students encounter red flags on their hike, it's time for them to count plant species to measure diversity (collect data).............but first...........

They will form a hypothesis (a guess or an estimate)

-"What habitat will make the most plants happy? (most sunlight, nutrients, etc.)

Phototropism - plants moving to get sunlight.

AW stations:

Flower Parts

-pollination

-bright petals attract bees, etc.

-style, stigma, stamen (male, anther + filament), pollen on anther

-pistil (female

-stigma (sticky) 
-style

-ovary: produces seed, all fruit is a swollen ovary.

-sepal/petal

Tree Guts

Forestry

Plot Surveys

Ethnobotany

-clothing, food, shelter, medicine

-etho: people/ botany: plants

Mushrooms (not actually plants)

-no choraphyll

-decomposers

-mushroom parts (poster)

-spores come from gills 